\title{
The ubiquitous octamer-binding protein Oct-1 contains a POU domain with a homeo box subdomain
}

\author{
Richard A. Sturm, Gokul Das, and Winship Herr \\ Cold Spring Harbor Laboratory, Cold Spring Harbor, New York 11724 USA
}

\begin{abstract}
The octamer motif ATGCAAAT is recognized indistinguishably by two mammalian transcription factors: one that is expressed ubiquitously and referred to here as Oct-1, and another, Oct-2, that is expressed in lymphoid cells. We report the cDNA cloning of the human oct-1 gene, which encodes Oct-1, by screening $\lambda$ gt11 recombinant phage in situ for octamer motif-specific DNA binding. One $\lambda$ gt11 recombinant expressed a $\beta$ galactosidase-octamer-binding fusion protein with a DNA-binding specificity indistinguishable from human HeLa cell Oct-1 protein. As expected for a ubiquitously expressed protein, Oct-1 mRNA is expressed in all five human and two mouse cell lines tested. Polyclonal rabbit antiserum raised against the $\beta$-galactosidase fusion protein shows that the DNA-binding domains of Oct-1 and Oct-2 proteins are related antigenically. Deletion analysis of the 743-amino-acid-long oct-1 open reading frame shows that the DNA-binding activity lies within a central highly charged domain of 160 amino acids. Comparison of the Oct-1 and Oct-2 sequences reveals that this domain is nearly identical between the two proteins. Highly similar domains are also present in the pituitary-specific transcription factor Pit-1 and the Caenorhabditis elegans unc-86 cell lineage gene product (see Herr et al. 1988). Within this shared POU (Pit-1, Oct-1 and Oct-2, unc-86) domain (pronounced 'pow') lie two subdomains: a POU-related homeo box and a POU-specific box. The Oct-1 protein is unique among the POUrelated proteins and other homeo box proteins because it is expressed ubiquitously.
\end{abstract}

[Key Words: Octamer; oct-1 gene; oct-2 gene; DNA-binding proteins; enhancer/promoter; replication]

Received October 1, 1988; revised version accepted October 17, 1988.

Transcriptional regulation depends largely on the sequence-specific interaction of trans-activator proteins with cis-acting promoter elements. Sequence-specific trans-activators contain two essential domains for function: a DNA-binding domain and a trans-activation domain. As first shown by fusion of the bacterial lexA DNA-binding domain to the yeast GAL4 trans-activation domain (Brent and Ptashne 1985), these domains can be interchanged. The specificity of transcriptional activation is conferred by the DNA-binding domain, which targets the trans-activator to the promoter carrying a corresponding DNA-binding site(s) (for review, see Ptashne 1988). To date, trans-activation domains have displayed little promoter specificity. For example, the yeast GAL4 trans-activator can stimulate a variety of promoters in mammalian cells provided that GAL4 DNA-binding sites are located in the vicinity of the promoter (Kakidani and Ptashne 1988; Ptashne 1988; Webster et al. 1988). Nevertheless, more than one class of trans-activation domain may exist because GAL4 fails to activate a U2 small nuclear RNA (snRNA) promoter containing GAL4 DNA-binding sites in mammalian cells (Tanaka et al. 1988).

The lymphoid-specific and ubiquitous octamer/de- camer (ATGCAAATNA)-motif-binding proteins provide a model system to study conservation of DNA-binding specificity, as well as to elucidate trans-activation specificity. The octamer motif (Falkner and Zachau 1984; Parslow et al. 1984), or closely related sequences, is a functional element in the promoters of the ubiquitously expressed snRNA (Ares et al. 1985; Mattaj et al. 1985; Mangin et al. 1986; Carbon et al. 1987) and histone H2B genes (LaBella et al. 1988; Sturm et al. 1988), a lymphoid-specific element in immunoglobulin upstream and enhancer regions (Falkner and Zachau 1984; Mason et al. 1985; Gerster et al. 1987; Lenardo et al. 1987; Wirth et al. 1987), and a DNA replication element in the adenovirus origin of replication (Pruijn et al. 1986; Rosenfeld et al. 1987). Two factors that bind indistinguishably to the octamer motif have been purified. One, first referred to as NF-Al (Staudt et al. 1986), is ubiquitously expressed, and the other, first called NF-A2 (Staudt et al. 1986), is restricted to lymphoid cells (Landolfi et al. 1986; Singh et al. 1986; Staudt et al. 1986; Rosales et al. 1987; Scheidereit et al. 1987). A 90 - to $100-\mathrm{kD}$ protein responsible for the ubiquitous octamer-binding activity has been purified from HeLa cells in several laboratories and variously referred to as OTF-1 (Fletcher et al. 1987), 
OBP100 (Sturm et al. 1987), or NFIII (O'Neill and Kelly 1988). OTF-1 and NFIII, which were initially shown to stimulate histone $\mathrm{H} 2 \mathrm{~B}$ transcription and adenovirus replication, respectively, are identical proteins $\left(\mathrm{O}^{\prime} \mathrm{Neill}\right.$ et al. 1988); OBP100 is probably also identical to OTF-1/ NFIII. The lymphoid-specific octamer-binding protein OTF-2 has also been purified (Scheidereit et al. 1987; Hanke et al. 1988) and stimulates transcription of an immunoglobulin light-chain $\kappa$ promoter in vitro (Scheidereit et al. 1987).

The different expression patterns of the ubiquitous octamer-binding protein, which we refer to here as Oct-1, and the lymphoid-specific octamer-binding protein, Oct-2 (Clerc et al. 1988, this issue), parallel the activity of the octamer motif in different contexts. In the context of a variety of RNA polymerase II promoters that direct expression of polyadenylated mRNAs (e.g., immunoglobulin, $\beta$-globin, SV40 earlyl, the octamer motif displays B-cell-specific enhancer function (Davidson et al. 1986; Gerster et al. 1987; Wirth et al. 1987; Tanaka et al. 1988). But in the context of the U2 snRNA promoter, which is also transcribed by RNA polymerase II (Frederiksen et al. 1978; Gram Jensen et al. 1979|, the octamer motif itself displays enhancer function in non-B cells (Mattaj et al. 1985; Ares et al. 1987; Tanaka et al. 1988). The different patterns of octamer motif function in a snRNA promoter, compared with the $\beta$-globin promoter, suggest that the ubiquitous octamer-binding protein belongs to a different class of trans-activators. Thus, the ubiquitous Oct-1 and lymphoid-specific Oct- 2 proteins are an excellent pair of trans-activators with which to study both conservation of DNA sequence recognition and divergence of trans-activation function.

We report here the isolation of human cDNA clones encoding ubiquitously expressed octamer-binding protein, referred to here as the oct-1 gene. First isolated as a $\lambda$ gt $11 \beta$-galactosidase fusion protein by the in situ DNA filter detection method (Singh et al. 1988; Staudt et al. 1988; Vinson et al. 1988), this protein meets several criteria (i.e., DNA-binding specificity, ubiquitous expression, antigenic relationship, and size) that indicate it is the ubiquitously expressed octamer-binding protein variously called OTF-1, NFIII, and OBP100. Comparison of the Oct-1 and lymphoid Oct-2 (Clerc et al. 1988) amino acid sequences reveals a highly conserved region, 160 amino acids long, that contains the DNA-binding domain and is also present in the pituitary transcription factor Pit-1 (Ingraham et al. 1988) and the Caenorhabditis elegans homeotic unc-86 gene product (Finney et al. 1988; see Herr et al. 1988, this issue).

\section{Results \\ Isolation of $\lambda$ C5: a $\lambda$ gt11 human cDNA recombinant encoding a $\beta$-galactosidase-octamer-binding fusion protein}

To isolate a cDNA clone of the ubiquitously expressed octamer-binding protein, we probed a human $\lambda g t l 1$ cDNA expression library for octamer-specific DNA- binding proteins by the in situ filter detection method (Singh et al. 1988; Staudt et al. 1988) using denaturation of filter-bound proteins to enhance the signal (Vinson et al. 1988). Because of the widespread expression pattern of the ubiquitous octamer-binding protein, we chose to screen a readily available $\lambda$ gt 11 cDNA library derived from the human teratocarcinoma cell line NTera-2D1 (constructed by J. Skowronski; SenGupta et al. 1986). This cell line displays elevated levels of ubiquitous octamer-binding activity (data not shown) and mRNA expression (see below). We screened $4 \times 10^{5}$ plaques with a radiolabeled multimerized SV40 octamer motif and identified one plaque (termed $\lambda \mathrm{C} 5$ ) that bound the probe effectively. Figure 1A shows that this binding is specific. Replica filter lifts from plates containing either partially purified $\lambda \mathrm{C} 5$ phage or L20 phage, which express a $\beta$-galactosidase-C/EBP fusion protein that binds specifically to C/EBP-binding sites (Landschulz et al. 1988b; Vinson et al. 1988), were probed with either the octamer motif or C/EBP-binding sites. Each recombinant fusion protein bound only to its corresponding probe (Fig. 1A).

To examine the $\beta$-galactosidase-octamer-binding fusion protein expressed by $\lambda \mathrm{C} 5$, bacterial extracts were prepared from $\lambda \mathrm{C} 5-, \lambda g t 11-$, and L20-infected cells and fractionated on a polyacrylamide gel (Fig. 1B). Compared with the uninfected cell extract (lane 5), the $\lambda C 5$-infected cell extract contains a $190-$ to $200-\mathrm{kD}$ protein and a series of smaller proteins of $\sim 150-190 \mathrm{kD}$. The $\lambda \mathrm{C} 5-$, $\lambda$ gtl 1-, and L20-encoded proteins were also tested for binding to the octamer motif after transfer to a filter. The larger of the $\lambda C 5$-specific proteins bound to the octamer motif probe (Fig. 1C, lane 2), but $\beta$-galactosidase ( $\lambda$ gt 11) and the C/EBP fusion protein (L2O) did not bind to the probe. The low level of binding by the major 150 to $190-\mathrm{kD}$ products present in Figure 1B suggests that many of these smaller $\lambda$ C5 proteins are missing the octamer motif DNA-binding domain. Some of the smaller proteins do, however, bind the octamer motif (Fig. 1C, lane 2), which may explain the heterogeneous pattern of complex formation observed in the gel retardation assays described below.

\section{$D N A$ binding specificity of the $\lambda C 5$ fusion protein}

To establish the authenticity of the octamer-specific DNA-binding activity of the $\lambda \mathrm{C} 5$ fusion protein, we tested its affinity for a number of known binding and nonbinding sites for the HeLa cell octamer-binding protein OBP100 in a gel retardation assay. OBP100 displays remarkably flexible DNA-binding specificity (Sturm et al. 1987; Baumruker et al. 1988|; in addition to binding to perfect octamer motifs [e.g., the immunoglobulin heavy-chain (IgH) enhancer octamer motif, ATGCAAAT], OBP100 binds to two degenerate SV40 octamer motifs and to the herpes simplex virus (HSV) TAATGARAT consensus sequence, which represents a very degenerate octamer motif (Baumruker et al. 1988). Figure 2 shows a comparison of the binding activities of Escherichia coli-derived $\lambda \mathrm{C} 5$ fusion protein and the partially purified OBP100 protein from HeLa cells. These 
Figure 1. Octamer motif binding of the $\lambda \mathrm{C} 5 \beta$-galactosidase fusion protein. $(A)$ Two replica filter lifts from plates containing partially purified $\lambda \mathrm{C} 5$ or the C/EBP-binding bacteriophage $\mathrm{L} 20$ were each screened reciprocally with ${ }^{32}$ P-labeled $14 \times B 17$ restriction fragment (OBP probe) or a ligated oligomer containing a C/EBP-binding site /C/EBP probe; Vinson et al. 1988). Each probe was radiolabeled by nick-translation and added to the respective filters at $1 \times 10^{5} \mathrm{cpm} / \mathrm{ml}$ after processing the filters by the guanidine hydrochloride denaturation/renaturation procedure (Vinson et al. 1988). $(B)$ One milliliter of log-phase $E$. coli strain Y1089 uninfected or infected with $\lambda C 5, \lambda g t 11$, or L20 at $5 \mathrm{pfu} / \mathrm{cell}$ was heat-shocked and subsequently treated with $10 \mathrm{~mm}$ IPTG for $1 \mathrm{hr}$. The cells were collected by centrifugation, and $20 \%$ of the total cell protein was fractionated on an $8 \%$ polyacrylamide-SDS gel after boiling in SDS-loading buffer. The fractionated proteins were visualized by Coomassie blue staining. (Lane 1) BioRad high-molecular-weight markers; (lane 2) $\lambda$ C5-infected cells; (lane 3) Agt 11 -infected cells; (lane 4) L20-infected extracts; (lane 5) uninfected cell extract. (C) Southwestern blot analysis was performed on four tracks equivalent to lanes $1-4$ in $B$. Following electrotransfer to nitrocellulose, the filter was probed with nick-translated $14 \mathrm{xB17}$ restriction fragment, as in $A$, without denaturation/renaturation treatment.

two proteins display the same relative affinity for each of these sites. The best binding site is the wild-type IgH enhancer octamer motif (lanes 1 and 2). The $\lambda$ C5-infected cell extract forms a major complex with a reduced mobility, compared with the bona fide OBP100 complex. This is consistent with the binding of the larger 190- to $200-\mathrm{kD} \lambda \mathrm{C} 5$ fusion protein. The more rapidly migrating complexes with the $E$. coli extract may reflect interac-
A
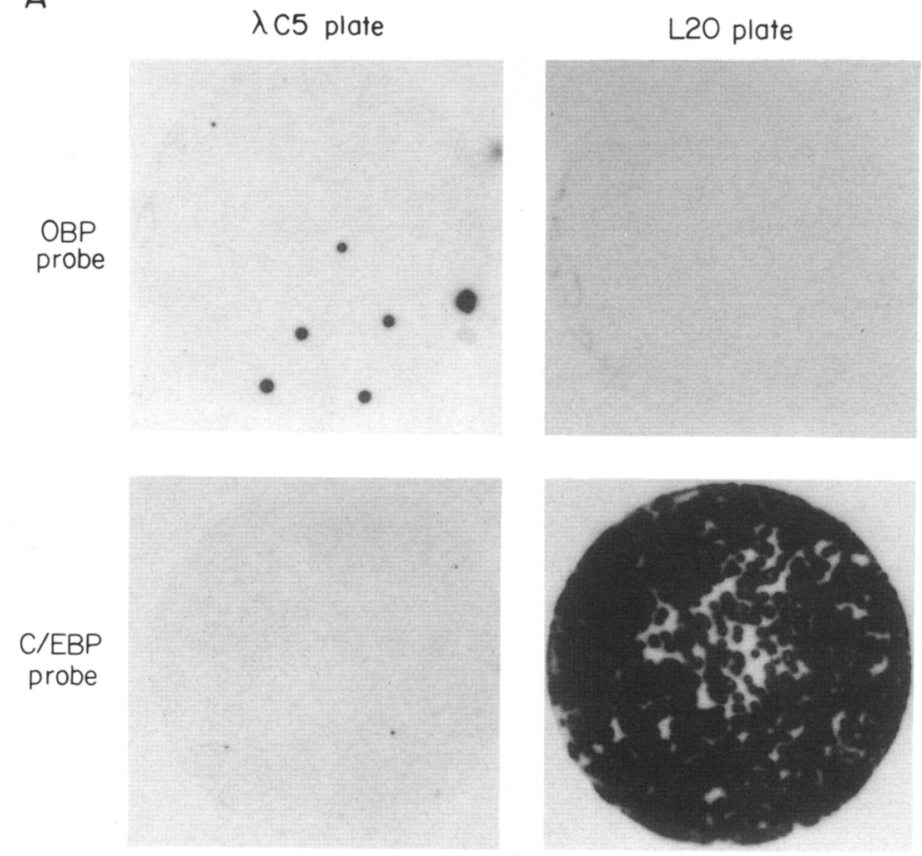

B

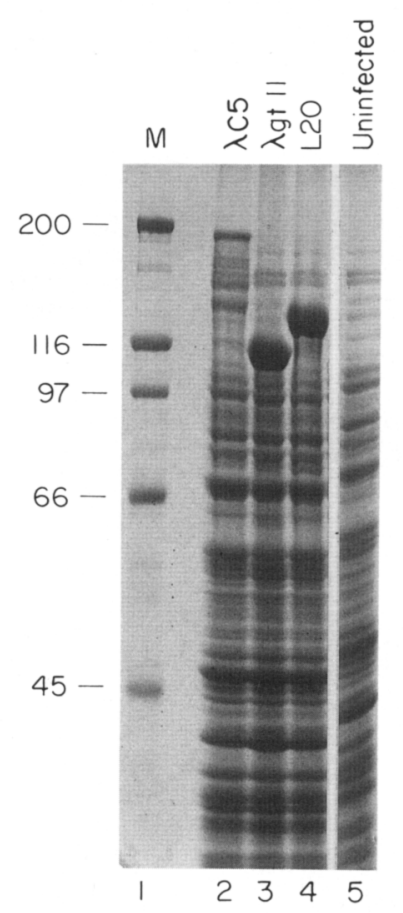

C

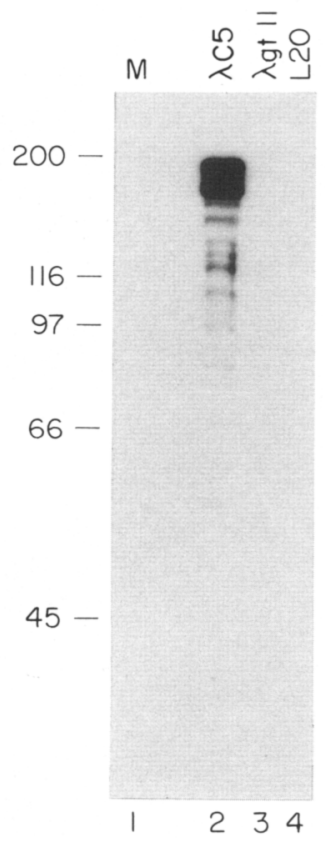

tions with smaller OBP fusion peptides present in the infected cell extract (see Fig. 1C). Whatever the case, all of the $\lambda \mathrm{C} 5$-specific complexes are also octamer specific because two point mutations within the nearly perfect SV40 Octal octamer motif (AaGgAAAG; $d p m 8$ ), which abolish OBP100 binding (Sturm et al. 1987; cf. lanes 3 and 4, Fig. 2), also prevent binding of all the $\lambda \mathrm{C} 5$ fusion proteins (cf. lanes 5 and 6 ). 


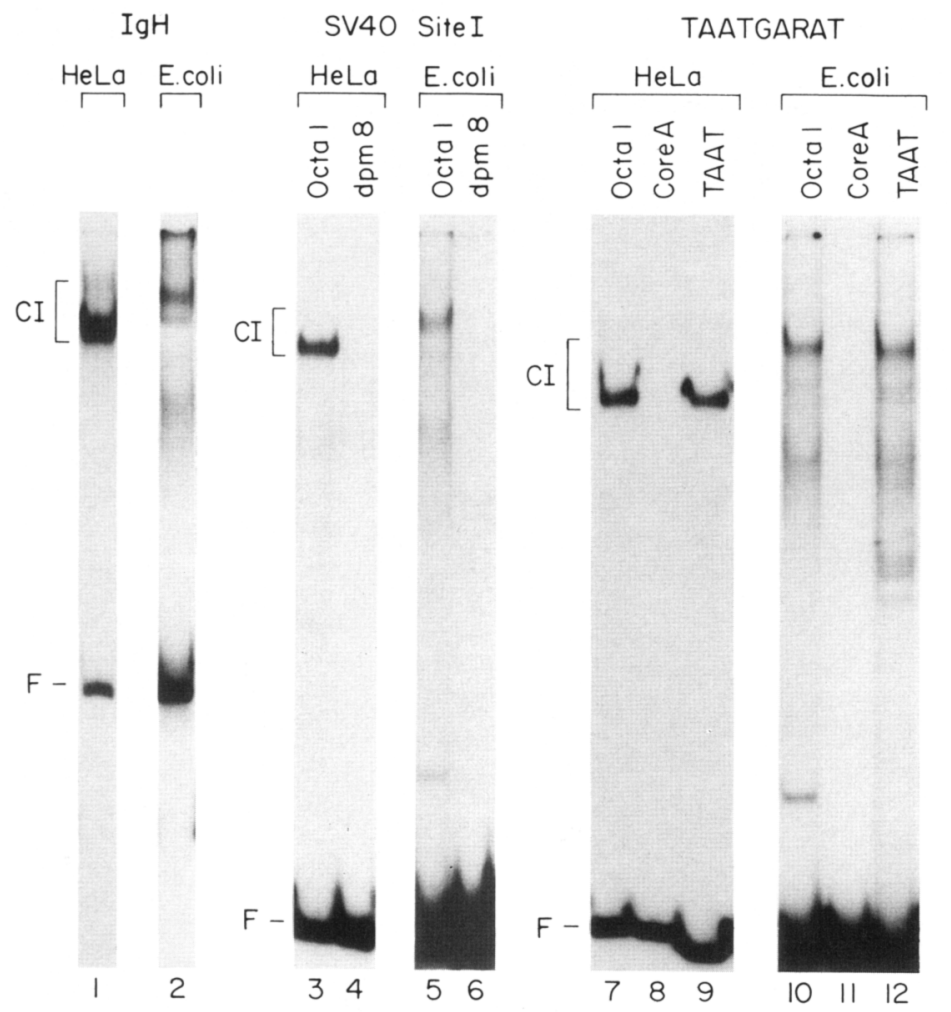

Figure 2. The $\lambda C 5 \beta$-galactosidase fusion protein displays the same relative affinity for multiple octamer protein-binding sites as HeLa-cell-derived OBP100. An E. coli extract was prepared from $\lambda \mathrm{C} 5$-infected cells /see Materials and methods) and DNA-binding activity assayed and compared to a partially purified OBP100 fraction from HeLa cells (Sturm et al. 1987) on three well-characterized OBP100-binding sites and two nonfunctional binding sites. Longer exposures of autoradiograms of the gel retardations produced by the bacterial extract are shown to compensate for the lower binding activity of the $\lambda C 5$-infected $E$. coli extract. The major octamer-specific complexes are indicated by the bracket and labeled CI. Restriction fragment probes end labeled with ${ }^{32} \mathrm{P}$ were assayed with either the HeLa or $E$. coli extracts, as described in Materials and methods, and indicated here. (Lanes 1, 2) A PstI-HindIII fragment containing $226 \mathrm{bp}$ of the murine IgH heavy-chain enhancer with a perfect consensus octamer motif ATGCAAAT (described in Sturm et al. 1987) and EcoRIPstI restriction fragments from pUCl19 containing binding sites cloned into the SmaI site; (lanes $3 / 7$ and 5/10) SV40 Octal-binding site; (lanes 4, 6) SV40 Octal with $d p m 8$ mutations; (lanes 8,11 ) the unrelated SV40 enhancer sequence core $A_{\text {; }}$ (lanes 9, 12) the HSV TAATGARAT sequence found to bind OBP100 (Baumruker et al. 1988).
The most stringent test of $\lambda \mathrm{C} 5$ fusion protein-binding specificity is the assay of TAATGARAT motif binding shown in lanes 7-12 of Figure 2. The SV40 Octal site (lanes 7 and 10) and TAATGARAT motif used here (lanes 9 and 12) are matched at only 4 out of 14 positions within the OBP100-binding site (Baumruker et al. 1988). OBP100 and the $\lambda$ C5 fusion protein display the same relative affinity for these two binding sites (cf. lanes 7 and 9 , and 10 and 12) but do not bind to an unrelated fragment (coreA, lanes 8 and 11). The relative affinity of $\lambda C 5$ fusion protein for a series of mutant and wild-type SV40 OBP100 site II sequences (Baumruker et al. 1988) was also similar to OBP100 (data not shown). Thus, the $\lambda C 5$ expressed protein displays the same binding specificity as authentic ubiquitous HeLa cell octamer-binding protein. In accordance with the nomenclature of Staudt et al. (1988) and Clerc et al. (1988), we refer to the gene encoding this octamer-binding protein as oct-1 and to the protein as Oct-1.

The oct-1 gene is expressed in all human and mouse cell lines tested

We expect the gene encoding the ubiquitous octamerbinding protein to be expressed ubiquitously. To detect expression, we performed an RNase protection assay, probing cytoplasmic RNAs from five human and two mouse cell lines with an antisense oct-1 RNA probe. This assay is very sensitive and stringent, because mismatches within an RNA-RNA duplex are targets for cleavage by RNase (Winter et al. 1985). Thus, it is a gene-specific expression assay. Figure 3 shows the result of probing cytoplasmic RNA from the human cell lines NTera-2D1, from which the cDNA library was derived; HeLa, either grown in spinner culture or on plates; 293, an adenovirus early-region-transformed embryonic kidney cell line; WI-38, a nontransformed lung fibroblast cell strain; and BJAB, a B-cell line containing a high concentration of the lymphoid-specific oct-2 mRNA (Staudt et al. 1988). The two mouse cell lines tested were NIH-3T3, and NS-1, a B-cell line. The human cell line RNAs all protect the complete oct-1 complementary sequences (468 nucleotides; see the asterisk in Fig. 3) within the probe (Fig. 3, lanes 2, 4, 6, 8, 9, and 10). Alkali treatment of the human RNA samples (lanes 3, 5, 7, and 11) prior to hybridization abolishes the signal, showing that the probe is being protected by RNA and not contaminating chromosomal DNA. The levels of oct-1 RNA are similar in each cell line except that the NTera-2D1 cell line has elevated oct-1 RNA levels (about three- to fivefold) and the WI-38 cell strain expresses less oct-1 RNA. These differences may reflect the relative growth rates of these cells because the NTera-2D1 cells grow rapidly, whereas the nontransformed WI-38 cells proliferate less rapidly.

Assay of the two mouse cell lines confirms that the protection assay is gene specific because the probe is no longer fully protected (Fig. 3, lanes 12 and 13). Instead, four shorter fragments (identified by the black dots) appear. These fragments probably represent RNase 
Figure 3. oct-1 mRNA expression in human and mouse cell lines. An RNase protection assay was performed using an internally labeled oct-1 antisense-RNA probe generated by T3 RNA polymerase from a template prepared by HaeIII digestion of $\mathrm{pBS} \lambda \mathrm{C} 51.1^{+}$, which contains the $5^{\prime}$ 1.1-kb oct-1 EcoRI fragment from $\lambda \mathrm{C} 5$ cloned into pBSM13 ${ }^{+}$. Except for the NIH-3T3 sample, which contained $10 \mu \mathrm{g}$ of RNA, $20 \mu \mathrm{g}$ of total cytoplasmic RNAs were hybridized, treated with RNase $A$ and $T_{1}$, and fractionated on a $6 \%$ denaturing polyacrylamide gel as described (Zinn et al. 1983). (Lane 1) Undigested probe alone; (lane 14) mock protection assay done in the absence of complementary RNA. Human cell line RNAs: (lanes 2, 3) NTera-2D1; (lanes 4, 5) HeLa cells from spinner culture; (lanes 6, 7) HeLa cells grown on plates; (lane 8) 293; (lane 9) WI-38; (lanes 10, 11) BJAB. Lanes labeled $\mathrm{OH}^{-}(3,5,7,11)$ contained RNA samples that had been hydrolyzed by pretreatment with $0.6 \mathrm{M}$ sodium hydroxide for 5-10 min at ambient temperature, followed by neutralization with acetic acid and ethanol precipitation. The 468-nucleotidelong fragment (nucleotides 642-1109 in Fig. 5A) protected in all of the human RNA samples is marked by an asterisk $\left({ }^{*}\right)$, and the appearance of a B-cell-specific band in the BJAB sample is indicated by an arrowhead. The mouse cell lines were NS-1 (lane 12) and NIH-3T3 (lane 13); the positions of four major protected fragments in these samples are indicated by black dots.

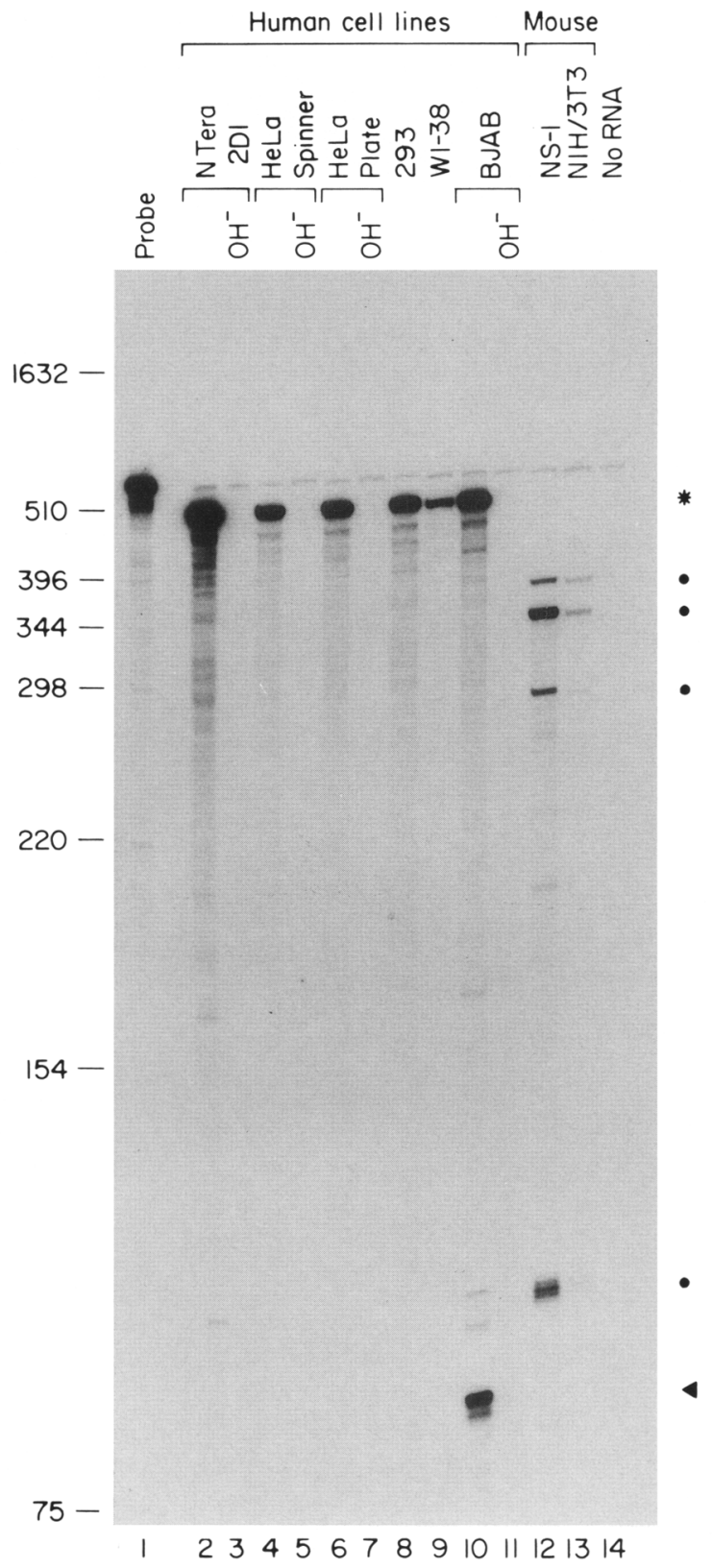

cleavage at mismatches between the human antisense probe and mouse oct-1 transcripts. The antisense oct-1 probe appears to cross-hybridize to oct-2 mRNA because an additional $\sim 100$-nucleotide-long oct-1 probe fragment is protected in the BJAB-derived RNA (Fig. 3, lane 10 , see arrowhead). This protected fragment is consistent with the very high degree of homology between the oct-1 and oct-2 genes within a portion of the region spanned by this probe (see below).

\section{Ubiquitous and lymphoid-specific octamer-binding proteins are related antigenically}

The experiments described above show that the protein encoded by the $\lambda \mathrm{C} 5 \mathrm{cDNA}$ clone has the same DNA- binding specificity as HeLa cell octamer-binding protein and that the gene is expressed ubiquitously. To verify further the relationship between ubiquitous octamerbinding protein and the $\lambda \mathrm{C} 5$ fusion protein, we prepared a rabbit antiserum directed against the $\beta$-galactosidaseoctamer-binding fusion protein (see Materials and methods). To test the effects of this antiserum on Oct-1 DNA binding, different dilutions of the antiserum (into preimmune serum/ were added to binding reactions with partially purified OBP100, and the effects on complex formation in a gel retardation assay are shown in Figure 4A. In these experiments, we observe a general and reproducible enhancement of complex formation by addition of preimmune rabbit serum, which is even more marked in the assays shown in Figure 4, B and C. Never- 


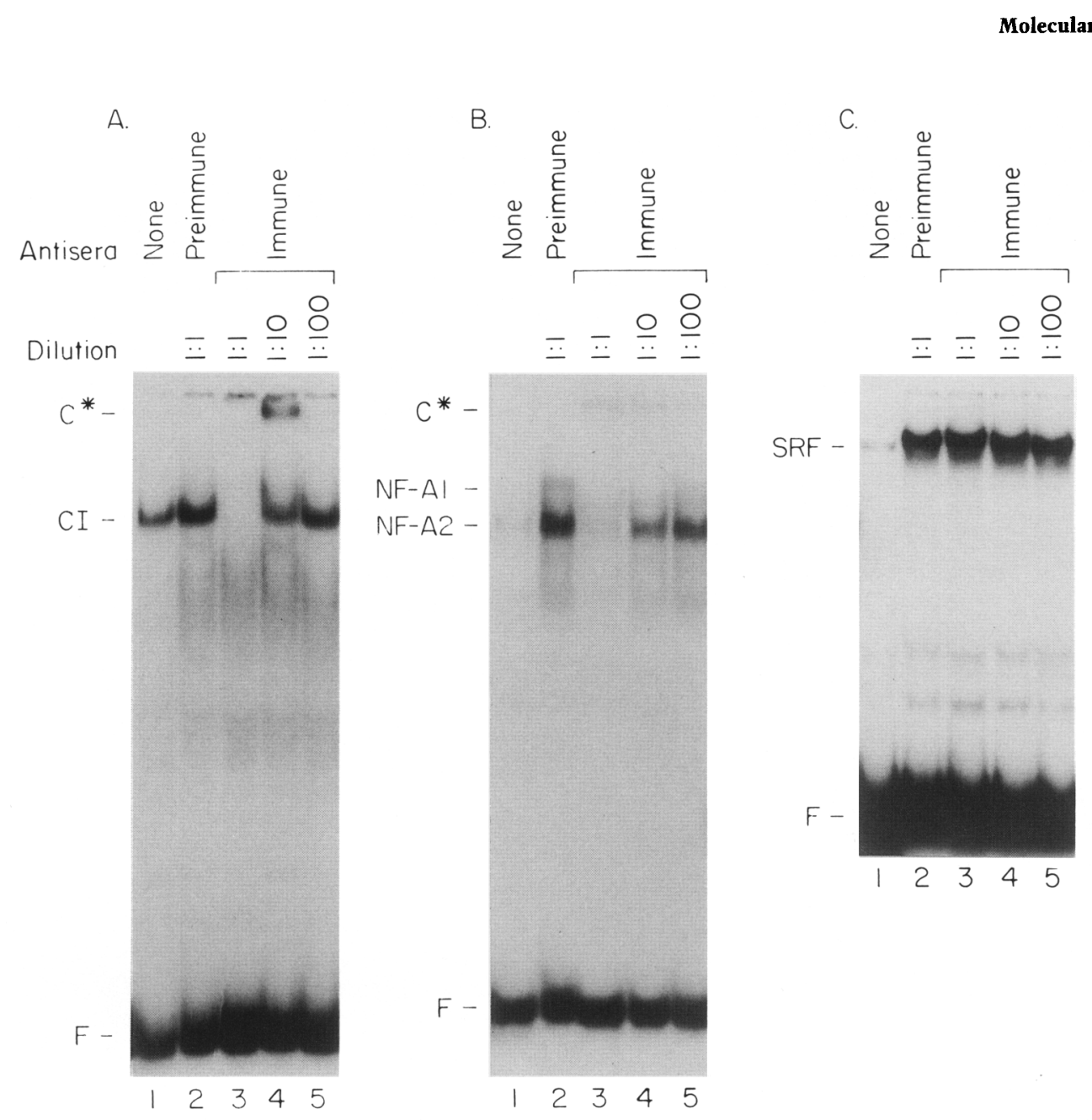

Figure 4. Rabbit anti-Oct-1 antiserum inhibits ubiquitous and lymphoid-specific octamer-binding activities. (A) A standard gel retardation assay (see Materials and methods) was performed using the wild-type SV40 site I probe in a 10- $\mu$ l binding mix containing a partially purified HeLa cell fraction enriched for OBP100. The effect of adding to the prebinding mix, either no rabbit antiserum (lane 1); $1 \mu \mathrm{l}$ preimmune antiserum (lane 2); $1 \mu \mathrm{l}$ immune serum (lane 3); $1 \mu 11: 10$ dilution immune serum (lane 4); $1 \mu \mathrm{l}$ of 1:100 dilution immune serum (lane 5). All immune serum dilutions were done with preimmune antiserum. Note the appearance of a second retardation complex $\left(C^{*}\right)$ upon dilution of the immune serum. (B) An Xhol end-filled fragment containing the SV40 Octal site was incubated with a total nuclear extract (Dignam et al. 1983) prepared from BJAB cells. The ubiquitous and B-cell-specific complexes NF-A1 and NF-A2 (Staudt et al. 1986) are indicated. Antisera were added to the binding mixes for lanes 1-5, as in $A$. (C) An end-labeled EcoRIHindIII fragment containing the c-fos SRE (Gilman 1988) was used in a binding mix with a heparin-agarose fractionated nuclear extract from H9 cells enriched for SRF (a gift from W. Ryan). The antisera added to the samples in lanes $1-5$ were as described in $A$. The strong enhancement of sequence-specific complex formation in $B$ and $C$ is a nonspecific effect of the added sera. The exact explanation for this effect is not known but may reflect a general enhancing effect of the added protein from the serum.

theless, addition of the $\lambda \mathrm{C} 5$ immune antiserum to the partially purified HeLa nuclear extract abolishes octamer-specific complex formation (Fig. 4A, lane 3) but not formation of complexes between the unrelated serum response factor (SRF) and the c-fos serum response element (SRE) (Fig. 4C, lanes 2-5). Tenfold dilution of the immune serum with the preimmune serum restored much of the octamer-specific complex but also generated a new complex with reduced mobility, labeled $\mathrm{C}^{\star}$ (lane 4). Further 10-fold dilution of the antiserum eliminated the $\mathrm{C}^{\star}$ complex and restored complex formation to the same level as with the preimmune serum.

We interpret these effects on octamer motif/Oct-1 complex formation as follows. At high concentrations, antibodies in the immune antiserum that are directed against the Oct-1 DNA-binding domain prevent complex formation. Upon dilution of the immune antiserum, the concentration of DNA-binding domain-specific antibodies is insufficient to inhibit all complex formation. At this concentration, antibodies directed against epitopes of the Oct-1 protein that are not involved in DNA binding can piggyback onto the Oct-1 protein/DNA complexes and create the $\mathrm{C}^{*}$ complex.

These results show that the $\lambda \mathrm{C} 5$ fusion protein is related antigenically to the ubiquitous octamer-binding protein. Similar experiments with a nonfractionated 
HeLa nuclear extract and NTera-2D1 nuclear extract, using wild-type and mutant octamer probes, showed that the CI complex is the only evident octamer-specific complex to form in these cell extracts and that all of the $\mathrm{CI}$ complexes are abolished by addition of the $\lambda \mathrm{C} 5 \mathrm{im}$ mune antiserum. These results suggest that there is only one major octamer-binding activity in these cells and that the oct-1 gene cloned in $\lambda \mathrm{C} 5$ encodes this protein.

Because the lymphoid-specific and ubiquitous octamer-binding proteins bind the octamer motif indistinguishably, we tested whether the DNA-binding domains of these two proteins might be antigenically related. Figure $4 \mathrm{~B}$ shows that this is indeed the case. When immune antiserum is added to $\mathrm{B}$ BJAB nuclear extract, both ubiquitous (labeled NF-A1; Staudt et al. 1986) and lymphoid-specific (NF-A2) octamer complex formation are inhibited (Fig. 4B, lane 3); but upon dilution of the immune serum, the octamer-specific complexes are restored. These results indicate that the Oct- 1 and Oct- 2 proteins contain antigenically related DNA-binding domains.

When the preimmune and immune $\lambda \mathrm{C} 5$ antisera were used in a Western blot of a HeLa cell nuclear extract, multiple species reacted, thereby preventing identification of the Oct-1 protein. In an immunoprecipitation of a radiolabeled 293 cell extract, however, among the many species that were immunoprecipitated, the only obvious difference between the preimmune and immune antisera precipitations was a protein of $\sim 95 \mathrm{kD}$ (data not shown). This molecular mass is consistent with the size of OTF-1 (Fletcher et al. 1987), NFIII (O'Neill and Kelly 1988), and OBP100 (Sturm et al. 1987).

\section{Nucleotide sequence of oct-1}

Figure 5A shows the 2584-nucleotide-long sequence of the oct-1 gene plus poly(A) sequence, as deduced from the $\lambda \mathrm{C} 5$ insert and from a $\lambda \mathrm{gt} 10$ oct $-1 \mathrm{cDNA}$ clone $(\lambda \mathrm{C} 7)$ described below. The $\lambda \mathrm{C} 5$ insert $(2424$ nucleotides long, excluding the EcoRI linkers) was sequenced in entirety on both strands and over all restriction sites by the chain-termination method (see Materials and methods). The nucleotide sequence of the $\lambda \mathrm{C} 5$ insert revealed an open reading frame, 762 amino acids long in-frame with the $\beta$-galactosidase-coding sequences. To characterize the $5^{\prime}$ and $3^{\prime}$ ends of the oct-1 mRNA, we isolated 16 independent $\lambda \mathrm{gt} 10$ clones from a separate NTera-2D1 cDNA library (provided by J. Skowronski; Skowronski et al. 1988), using the $\lambda$ C5 insert as the probe. Analysis of these cDNAs showed that they were either similar in size or shorter than the $\lambda \mathrm{C} 5$ insert, suggesting that the $\lambda \mathrm{C} 5$ insert is nearly full length. Nucleotide sequence analysis of the $5^{\prime}$ and $3^{\prime}$ termini of the longest $\lambda \mathrm{gt} 10$ cDNA clone, $\lambda \mathrm{C} 7$, extended the $5^{\prime}$ oct-1 nucleotide sequence by $9 \mathrm{bp}$ and revealed the nucleotide sequence of the entire $3^{\prime}$-untranslated region. Not shown in Figure $5 \mathrm{~A}$ is the presence of an extra sequence in $\lambda \mathrm{C} 7,102 \mathrm{nu}$ cleotides long, located near the $5^{\prime}$ end, which may reflect alternative splicing. An extensive analysis of $\lambda \mathrm{C} 7$ and the other cDNAs will be described in a separate communication.
Determination of the exact position of the $5^{\prime}$ end of the oct-1 mRNA by primer extension and determination of mRNA size by Northern blotting have been hampered by a low abundance of oct-1 mRNA. The inability to extend significantly the $5^{\prime}$ sequence of $\lambda \mathrm{C} 5$ by isolation of multiple cDNAs suggests that in $\lambda \mathrm{C} 5$, the $\beta$-galactosidase fusion is into the 5 '-untranslated region of the oct-1 mRNA. Therefore, we tentatively assign the first inframe ATG codon 160 nucleotides downstream of the start of the oct-1 sequence shown in Fig. 5A) as the initiation codon for the oct-1 encoded protein Oct-1 and number both the nucleotide and amino acid sequence from this point. This assignment predicts that the Oct-1 protein is 743 amino acids long with an estimated molecular mass of $76 \mathrm{kD}$. However, as described below, the in vitro translation product from this cDNA has a considerably larger apparent molecular mass of between 90 and $94 \mathrm{kD}$.

The amino acid composition of the predicted Oct- 1 protein is enriched for glutamine $(11 \%)$, serine $(14 \%)$, threonine $(10 \%)$, and proline $(7 \%)$. Whereas the proline residues are rather evenly distributed throughout the Oct-1 protein, the glutamine residues are highly concentrated within the amino-terminal third of the protein (26\% from amino acid $22-268$; see Fig. $5 \mathrm{~B}$ ). The entire protein is rich in serine and threonine residues, but the region from amino acid 441 to 560 is particularly Ser/ Thr rich, as $50 \%(60 / 120)$ of these residues are either serine or threonine. A high concentration and uneven distribution of glutamine, and serine and threonine residues is reminiscent of the ubiquitous mammalian transcription factor Sp1 (Kadonaga et al. 1987). Unlike Sp1, however, the Oct-1 protein does not contain zinc finger motifs consistent with the $\mathrm{Zn}^{2+}$-independent DNAbinding activity of the ubiquitous octamer-binding protein (Westin and Schaffner 1988). The central portion of the oct-1 coding sequence is very rich in both basic and acidic amino acids. From residue 272 to $436,18 \%$ $(29 / 165)$ of the residues are either arginine or lysine and $14 \%(23 / 165)$ are the acidic residues aspartic or glutamic acid. It is this 165 -amino-acid-charged domain that contains the DNA-binding domain (see below).

Amino acid sequence comparison between the Oct-1 and Oct-2 proteins reveals a highly conserved domain

One of our primary interests in cloning the ubiquitous octamer-binding protein is to understand how it shares the same DNA-binding specificity as the lymphoid-specific octamer-binding protein but apparently differs in trans-activation function. Therefore, we compared the amino acid sequence of Oct-1 with the Oct-2 sequence determined by Clerc et al. (1988). As shown in Figure $6 \mathrm{~A}$, the amino-terminal regions of the two proteins display significant but patchy homology, in part reflecting the glutamine-rich composition of these two proteins within this region. The carboxy-terminal regions display only a few short regions of sequence similarity. Curiously, in Oct-2, these short sequence similarities are juxtaposed to create a leucine zipper motif (Landschulz 
A.

GAGGAGCAGCGAGTCAAGATGAGAGTTCAGCCGCGGCGGCAGCAGCAGCAGACTCAAGAATGAACAATCCGTCAGAAACCAGTAAACCATCTATGGAGAGTGGAGATGGCAACACAGGC

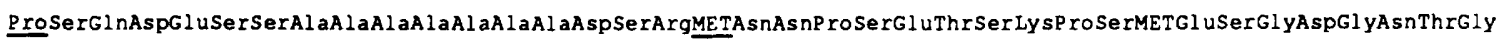
$\beta-g a l \rightarrow 1-\lambda c 5 \rightarrow$

BstXI

ACACAAACCAATGGTCTGGACTTTCAGAAGCAGCCTGTGCCTGT AGGAGGAGCAATCTCAACAGCCCAGGCGCAGGCTTTCCTTGGACATCTCCATCAGGTCCAACTCGCTGGAACAAGT

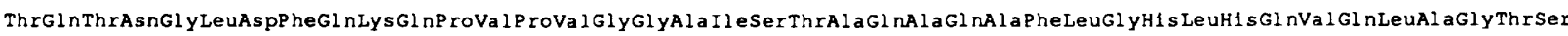
-Gln rich $\rightarrow$

TTACAGGCTGCTGCTCAGTCTTTAAATGTACAGTCTAAATCTAATGAAGAATCGGGGGATTCGCAGCAGCCAAGCCAGCCTTCCCAGCAGCCTTCAGTGCAGGCAGCCATTCCCCAGACC

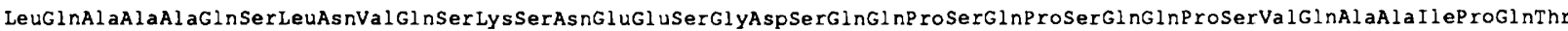

CAGCTTATGCTAGCTGGAGGACAGATAACTGGGCTTACTTTGACGCCTGCCCAGCAACAGTTACTACTCCAGCAGGCACAGGCACAGGCACAGCTGCTGGCTGCTGCAGTGCAGCAGCAC

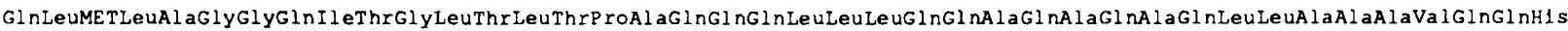

TCCGCCAGCCAGCAGCACAGTGCTGCTGGAGCCACCATCTCCGCCTCTGCTGCCACGCCCATGACGCAGATCCCCCTGTCTCAGCCCATACAGATCGCACAGGATCTTCAACAACTGCAA

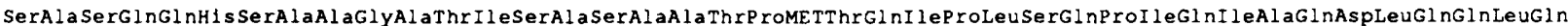
«Gln rich-1

60 20 180 60 300 100

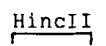

ATTCAGACACTTCCACAGAGCCAGTCAACACCAAAGCGAATTGATACTCCCAGCTTGGAGGAGCCCAGTGACCT TGAGGAGCTTGAGCAGTTTGCCAAGACCTTCAAACAAAGACGAA TC

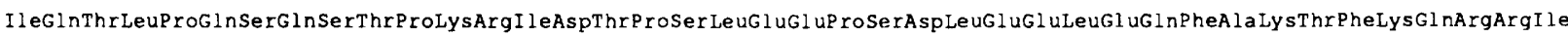
$\leftarrow$ Gln $\mathrm{rich} \rightarrow 1$

$$
\text { Acidic/Basic } \rightarrow
$$

AAACTTGGATTCACTCAGGGTGATGTTGGGCTCGCTATGGGGAAACTATATGGAAATGACTTCAGCCAAACTACCATCTCTCGATTTGAAGCCTTGAACCTCAGCTTTAAGAACATGTGC

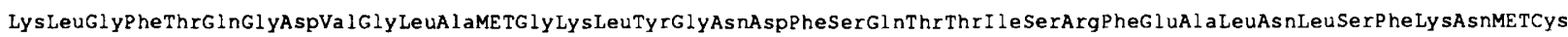

AAGTTGAAGCCACTTTTAGAGAAGTGGCTAAATGATGCAGAGAACCTCTCATCTGATTCGTCCCTCTCCAGCCCAAGTGCCCTGAATTCTCCAGGAATTGAGGGCTTGAGCCGTAGGAGG 1140

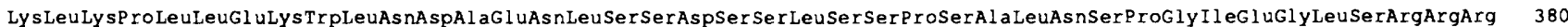

AAGAAACGCACCAGCATAGAGACCAACATCCGTGTGGCCTTAGAGAAGAGTTTCTTGGAGAATCAAAAGCCTACCTCGGAAGAGATCACTATGATTGCTGATCAGCTCAATATGGAAAA 1260

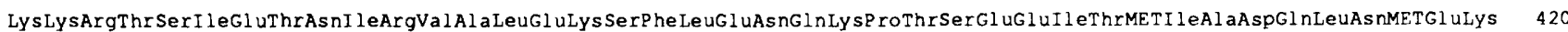
H

$$
\text { PfIMI }
$$

GAGGTGATTCGTGTTTGGTTCTGTAACCGCCGCCAGAAAGAAAAAAGAATCAACCCACCAAGCAGTGGTGGGACCAGCAGCTCACCTATTAAAGCAATTTTCCCCAGCCCAACTTCACTG 1380 Gl uVal I l eArgValTrpPheCYSAsnArgArgGlnLysGluLysArgI leAsnProProSerSerGlyGlyThrSerSerSerProI leLYsAlaI lePheProSerProThrSerLeu 460
r

$$
\mathrm{H}
$$$$
\leftarrow \text { Acidic/Basic } \longrightarrow
$$$$
\text { -Ser/Thr rich } \rightarrow
$$

GTGGCGACCACACCAAGCCTTGTGACTAGCAGTGCAGCAACTACCCTCACAGTCAGCCCTGTCCTCCCTCTGACCAGTGCTGCTGTGACGAATCTTTCAGTTACAGGCACTTCAGACACC 15OO ValAlaThrThrProSerLeuValThrSerSerAlaAlaThrThrLeuThrVal SerProVal LeuProLeuThrSerAlaAlaValThrAsnLeuSerValThrGlyThrSerAspThr SOO

$$
\text { HaeII }
$$

ACCTCCAACAACACAGCAACCGTGATTTCCACAGCGCCTCCAGCTTCCTCAGCAGTCACGTCCCCCTCTCTGAGTCCCTCCCCTTCTGCCTCAGCCTCCACCTCCGAGGCATCCAGTGCC 1620 ThrSerAsnAsnThrAlaThrVal IleSerThrAlaProProAlaSerSerAlaValThrSerProserLeuSerProSerProSerAlaSerAlaSerThrSerGluAlaSerSerAla 540

AGTGAGACCAGCACAACACAGACCACCTCCACTCCTTTGTCCTCCCCTCTTGGGACCAGCCAGGTGATGGTGACAGCATCAGGTTTGCAAACAGCAGCAGCTGCTGCCCTTCAAGGAGCT 1740 SerGluThrSerThrThrGlnThrThrSerThrP roLeuSerSerProLeuglyThrSerGlnValMETValThrAlaserglyLeugInThrAlaAlaAlaAlaAlaLeuGInGlYAla 5BO $\leftarrow$ Ser/Thr rich $\rightarrow$

Figure 5. (See following page for legend.) 
et al. 1988a; Clerc et al. 1988/ that is not present in Oct-1.

The most striking region of similarity between Oct-1 and Oct-2 lies within the centrally located 160-aminoacid-long highly charged domain extending from residue 280 to residue 439 in Oct-1 (Oct- 2 has three additional residues). In this region, these two proteins share identical residues at $142 / 160$ positions. This represents $89 \%$ sequence similarity. The amino-terminal half of this conserved domain displays the highest degree of similarity; 74 out of 75 residues are identical. The amino-terminal portion of these 75 residues contains the sequence PSDLEELE, which is a consensus casein kinase II (CKII) phosphorylation site (Kuenzel et al. 1987), and there is a second adjacent potential CKII phosphorylation site (PSLEE in Oct-1) just upstream. The central portion of the shared charged domain is less related, displaying $\sim 50 \%$ identity ( 14 out of 24 positions in Oct- 1 ). The remainder of the charged domain (residues 378-439) is $89 \%$ identical. This latter region contains a putative helix-turn-helix motif, characteristic of many DNAbinding proteins (Pabo and Sauer 1984), and is distantly but significantly related to the homeo box motif first identified in Drosophila homeotic genes (McGinnis et al. 1984; Scott and Weiner 1984).

Figure $6 \mathrm{~B}$ shows a sequence comparison between the

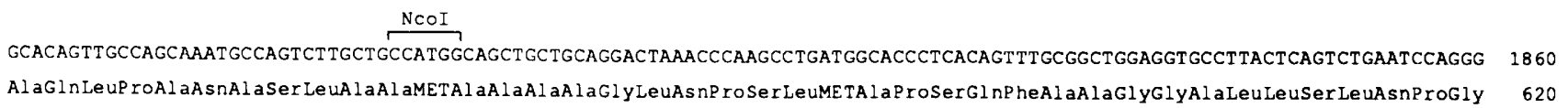

ACCCTGAGCGGTGCTCTCAGCCCAGCTCTAATGAGCAACAGTACACTGGCAACTATTCAAGCTCTIGCTTCTGGTGGCTCTCTTCCAATAACATCACTTGATGCAACTGGGAACCTGGTA 1980

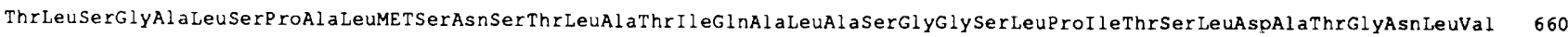

TTTGCCAATGCGGGAGGAGCCCCCAACATCGTGACTGCCCCTCTGTTCCTGAACCCTCAGAACCTCTCTCTGCTCACCAGCAACCCTGTTAGCTTGGTCTCTGCCGCCGCAGCATCTGCA 2100 PheAlaAsnAlaGlYGIYAlaP roAsri leValThrAlaProLeuPhe LeuAsnProGlnAsnLeuSerLeuLeuThrSerAsnProval SerLeuVal SerAlaAlaAlaAlaSerAla 700

GGGAACTCTGCACCTGTAGCCAGCCT TCACGCCACCTCCACCTCTGCTGAGTCCATCCAGAACTCTCTCTTCACAGTGGCCTCTGCCAGCGGGGCTGCGTCCACCACCACCACCGCCTCC 2220 GlyAsnSerAlaProValAlaSerLeuHisAlaThrSerThrSerAlaGl USerIleGlnAsnSerLeuPheThrValAlaSerAlaSerGlyAlaAlaSerThrThrThrThrAlaSer 740

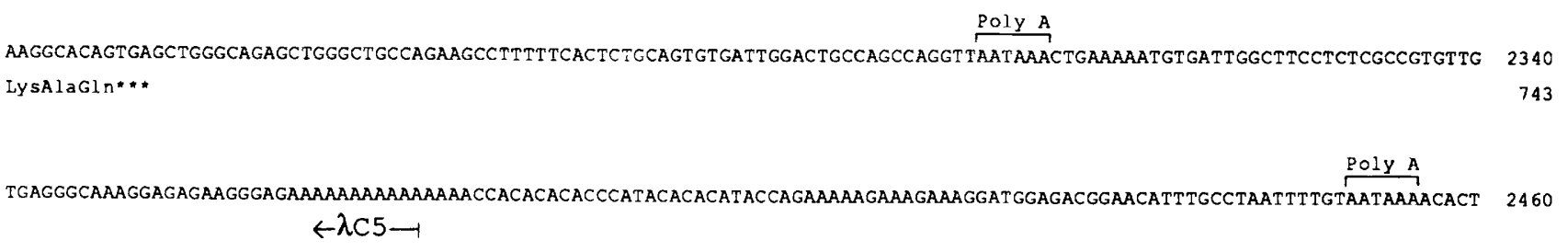

B.

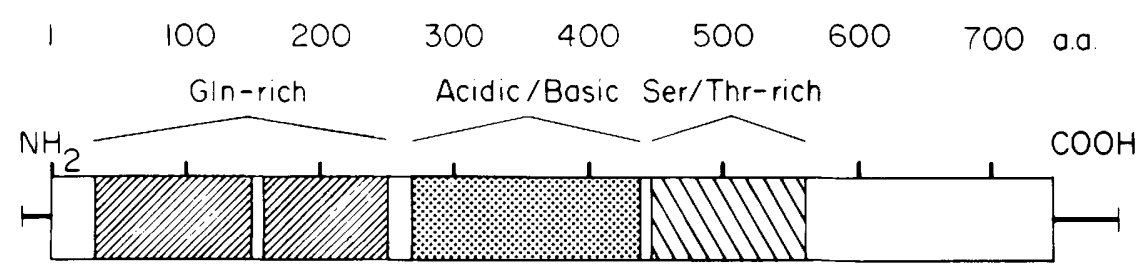

Figure 5. Nucleotide sequence of human oct-1 and deduced amino acid sequence of the Oct-1 protein. $(A)$ The DNA sequence and deduced amino acid sequence of the oct 1 gene derived from the $\lambda C 5$ clone and the overlapping $\lambda C 7$ clone. The numbering system shown at the right of the sequence begins for both nucleotide and peptide sequences at the putative initiation codon ATG (labeled 1 over the underlined MET; Kozak 1984). The position of the fusion of oct-1 to $\beta$-galactosidase in $\lambda C 5$ is indicated, and the extra proline residue encoded by the EcoRI linker oct-1 junction sequence is underlined; the $3^{\prime}$ end of the $\lambda C 5$ clone is also indicated. Glutamine, acidic/basic, and serine/threonine-rich regions, discussed in the text, are bounded by arrows. The position of restriction enzymes used in the mapping of the oct-1 DNA binding-domain are highlighted on the sequence, and the helix-turn-helix motif is represented below the amino acid sequence by the two boxes (helixes) joined by the line (turn). The position of two consensus polyadenylation hexamers, AATAAA, is also indicated. $(B)$ A schematic illustration of the structure of the deduced 743-amino-acid reading frame of the Oct-1 protein beginning at the predicted initiator MET (amino acid 1 in $A$ ). The regions outlined by arrows in $A$ are boxed and shaded in $B$. 


\begin{abstract}
A.

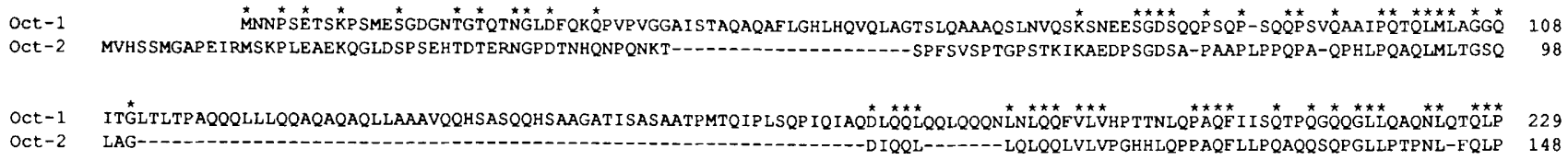

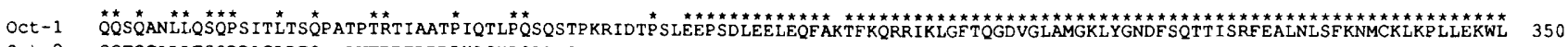
OCt-2 QQTQGALITSQPRAGLPTQ-AVTRPTLPDPHLSHPQPPKCLEPP SHP--EEFSDLEELEQF ARTFKQRRIKLGETQGDVGLAMGKLYGNDFSQTTISRFFEAINLSFKNMCKLKPLLEKWL 265

OCt-1 $\begin{aligned} & \star \star \star \star * \\ & \text { NDAENLS }\end{aligned}$ OCt-2 NDAE TMS VDSSLP SPNQLSSP SLGFDGLPGRRRKKRTS IETNVRF ALEKSF LANOKP TSEEILI IAEQLHMEKEVIRVWECNRRQKEKRINPCSAA--.----PMLP SPGKP ASYSP HMV 378 $\stackrel{\leftrightarrow}{\longrightarrow}$

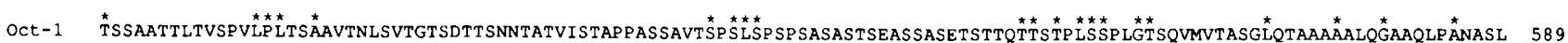
Oct-2 TPQGGAG--.--TLPLSQA-_...-

OCt-1 AAMAAAAGLNPSLMAP SQFAAGGALLSLNPĞTLSGALSPALMSNSTLATIQALASGGSLP ITSLDATGNLVFANAGGAPNIVTAPLFLNPQNLSLLTSNPVSLVSAAAASAGNSAPVASLH 710 OCt-2 SIPSVTPPPPATTNSTNPSPQGSHSAIGLSGLNPSTG

Oct-1 ATSTSAESIQNSLFTVASASGAASTTTTASKAQ

B.

Figure 6. Sequence homology between Oct-1 and he Oct-1 homeo box domain and both prototypic Drosophila homeo box domains and the C. elegans unc-86 gene product (Finney et al. 1988). (A) The Oct-1 and Oct-2 protein sequences are shown in the one-letter code and have been aligned for maximum homology. Positions of identity between the two sequences are indicated by the asterisks (*) above the sequence, and the POU-specific and POU-related homeo box domains are shown below the sequence. $(B)$ The amino acid sequence of the Oct-1 homeo box region is compared with Oct-2 (Clerc et al. 1988), unc-86 (Finney et al. 1988), eve (Macdonald et al. 1986), Antp (Schneuwly et al. 1986), and en (Poole et al. 1985) homeo box domains. The dots below the Oct-1 sequence represent positions of identity. A homeo box consensus sequence (Scott et al. 1989) is shown for comparison above the Oct-1 sequence. The position of variable amino acids in the consensus sequence is shown by dashes, and those conserved residues aligning with the Oct-1 sequence are indicated by the vertical lines. The number of residues shared with the Oct-1 sequence in the 60-amino-acid homeo box region is tabulated to the right of each sequence.
\end{abstract}

homeo box region of Oct-1 and Oct-2 and the homeo box region of three different prototypic Drosophila homeo box proteins: even-skipped (eve), Antennapedia (Antp), and engrailed (en) and the recently described C. elegans unc-86 cell lineage gene product (Finney et al. 1988). Also included is a homeo box consensus sequence developed by Scott et al. (1989), after comparing 83 different homeo box motifs (including Oct-1). The Oct-1 homeo box domain shares identity with the homeo box domains of Eve, Antp, and En at 21/60, 20/60, and 14/60 positions, respectively. This region of Oct-1 also shares 11 out of the 21 highly conserved residues established in the homeo box consensus sequence. Although the sequence relationship is concentrated in the carboxy-terminal third of the domain, within and adjacent to the putative DNA recognition helix of the helix-turn-helix motif, there are four significant sequence identities outside of this region (see Fig. 6B).

Comparison of the Oct-1 and Oct-2 homeo-box-related domains to the homeo-box-related domain in the unc-86 gene product (Finney et al. 1988) shows a considerably higher level of homology between one another $(28 / 60$ between Oct-1 and unc-86) than with the other homeo box proteins. The homeo box domain described in the pituitary-specific transcription factor Pit-1 (Ingraham et al. 1988) is also closely related to the Oct-1 homeo box. These results indicate that Pit-1, Oct-1, Oct-2, and unc-86 form a related family. Surprisingly, this same family is even more related to one another within the 75-amino-acid region that is nearly identical 
between Oct-1 and Oct-2 (see Herr et al. 1988 and discussion below). Because the entire 160-amino-acid-long charged region is conserved among these four proteins, we refer to it as the POU (Pit-1, Oct-1 and Oct-2, and unc-86)-related domain (pronounced 'pow').

\section{The Oct-1 DNA-binding domain lies within the highly conserved $P O U$ domain}

To map the Oct-1 DNA-binding domain, we used in vitro-translated Oct-1 protein in gel retardation assays, as first described by Hope and Struhl (1985). The entire $\lambda C 5$ insert was cloned into the BlueScript vector $(\mathrm{pBS}$ $\mathrm{Ml3}^{+}$; Stratagene), which carries opposing T3 and T7 bacteriophage RNA polymerase promoters. To produce full-length Oct-1 protein and mutant derivatives, sense oct-1 RNA was transcribed in vitro with T7 RNA polymerase and the RNA translated in an in vitro rabbit reticulocyte translation system. The expression construct was designed so that the first AUG codon in the in vitro transcribed RNA is the first ATG in the $\lambda$ C5 insert (labeled nucleotide 1 in Fig. 5A). The in vitro-translated proteins were analyzed by polyacrylamide gel electrophoresis and subsequently used in a gel retardation assay with radiolabeled wild-type and mutant octamer-containing DNA fragments. The largest oct-1 in vitro translation product has an apparent molecular mass of about $90-94 \mathrm{kD}$, considerably larger than the predicted $76 \mathrm{kD}$ of the 743-amino-acid-long $\lambda$ C5-encoded protein but, nevertheless, $\sim 2-5 \mathrm{kD}$ smaller than purified HeLa cell octamer-binding protein (data not shown). This difference could reflect usage of the wrong initiation codon or lack of appropriate modifications.

Figure 7A shows the different deletions that were tested for DNA-binding activity in a gel retardation assay. Figure 7B shows a gel retardation assay with the Oct-1 carboxy-terminal deletions. In each case, the proteins were mixed with labeled DNA fragments containing the wild-type SV40 octamer motif (odd-numbered lanes) or the double point mutant $d p m 8$ (evennumbered lanes). Authentic HeLa cell octamer-binding protein was used as a marker (lanes 1 and 2). Addition of the rabbit reticulocyte extract itself (lanes 3 and 4) pro- duced a weak endogenous octamer-binding activity that is not visible on the exposure shown. The full-length in vitro translation product produced a gel retardation complex with a slightly greater mobility than the authentic HeLa cell octamer-binding protein (cf. lanes 1 and 5), consistent with the somewhat smaller apparent molecular weight of the in vitro translated product. The largest carboxy-terminal truncation that still retained octamer-specific DNA-binding activity mapped to the carboxyl terminus of the homeo box domain (PfIMI site at amino acid 440; see Fig. 5A) (cf. lanes 11 and 12). Truncation of an additional 26 residues removed the 'recognition' helix of the helix-turn-helix motif and abolished DNA-binding activity (BclI, lane 13), as did removal of the entire POU domain (HincII, lane 15). This result shows that the homeo box motif is required for DNA binding, whereas the sequences carboxy terminal to the homeo box are dispensable.

To determine whether the entire conserved POU domain is sufficient for DNA binding, we deleted the amino-terminal domain from residue 23 to 270 , just 19 residues upstream of the POU domain (see Figs. 5A and $7 \mathrm{~A})$. By retaining the same 5 - -untranslated region plus 70 nucleotides of coding sequence, we decreased the likelihood of a change in initiation codon usage during the in vitro translation. Figure $7 \mathrm{C}$ shows the effect of this amino-terminal deletion. Either with (HindIII; lanes 3 and 4$)$ or without (PfIMI; lanes 5 and 6$)$ the sequences downstream of the homeo box domain, this amino-terminal deletion still binds specifically to the octamer motif. These results indicate that the POU-conserved domain is sufficient for DNA sequence recognition, although we cannot preclude that the amino-terminal 23 residues are not also required.

\section{Discussion}

We have described the isolation and characterization of human oct-1 cDNA clones encoding the ubiquitously expressed octamer-motif-binding protein Oct-1. This gene probably encodes the HeLa cell octamer-binding protein that has been isolated and named differently by several groups, i.e., OTF-1 (Fletcher et al. 1987), NFIII

Figure 7. Deletion mapping of the Oct-1 octamer-motif-binding domain. (A) A schematic illustration of the structure of the oct-1 protein product produced by in vitro translation of mRNA templates produced from pBSoct- $1^{+}$. The 743 -amino-acid reading frame is boxed, and the glutamine, acidic/basic, and serine/threonine-rich regions described in Fig. 5, are shaded. The truncations and internal deletion used to map the DNA-binding region of the protein are outlined below the schematic figure, and the corresponding restriction enzymes and DNA-binding activity are listed on the right. The region sufficient for binding activity is indicated by the arrow. The positions of the POU domain and the POU-specific and homeo-related boxes are shown at the bottom. $(B)$ The gel retardation assay was performed with the B20 end-labeled EcoRI-PstI restriction fragments from pUC119 containing the wild-type SV40 OBP100binding site 1 (odd-numbered lanes) or with the $d p m 8$ mutations (even-numbered lanes). (Lanes 1, 2) Partially fractionated HeLa cell OBP100 as a marker; (lanes 3,4) no RNA added to the rabbit reticulocyte in vitro translation system as a negative control; (lanes 5, 6) full-length Oct- 1 in vitro translation product generated from HindIII-digested pBSoct-1 ${ }^{+}$. Truncations were with restriction enzymes as follows: (lanes 7, 8) NcoI; (lanes 9, 10) HaeII; (lanes 11, 12) PfIMI; (lanes 13, 14) BclI; (lanes 15, 16) HincII. (C) The gel retardation assay was performed as in $B$ : (lanes 1,2) full-length Oct-1 in vitro translation product; (lanes 3, 4) the BstXI-HincII amino-terminal deletion of pBSoct-1 $1^{+}$; (lanes 5, 6) the PfIMI truncation of the BstXI-HincII amino-terminal deletion. 
A.

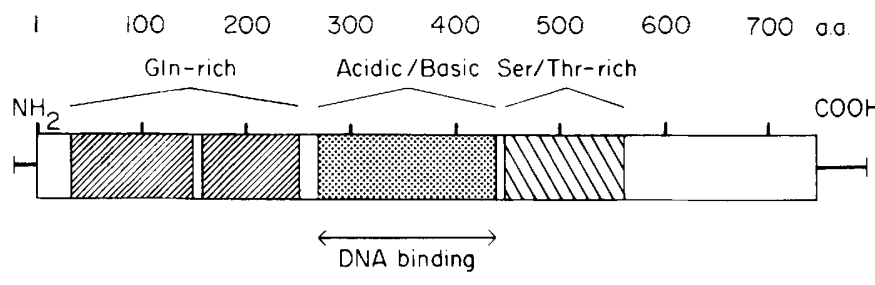

Truncation

Hind III

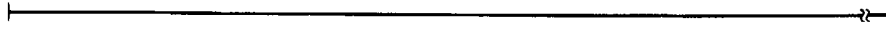

Nco I

Hoe II

PfIMI

Bcl I

Hinc I

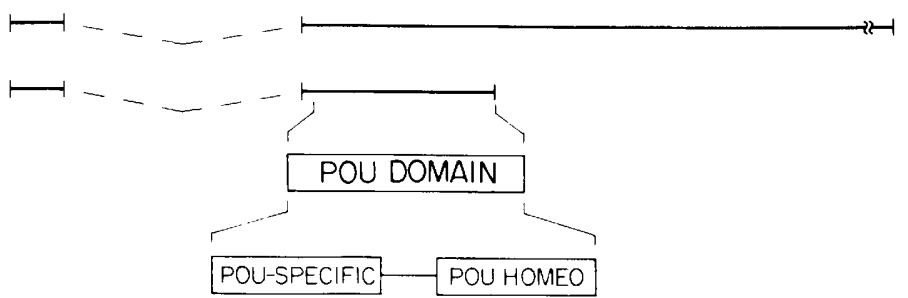

$\Delta$ Bst XI-Hinc II/ Hind III

$\triangle$ Bst XI-Hinc I/ + PfIMI

B.
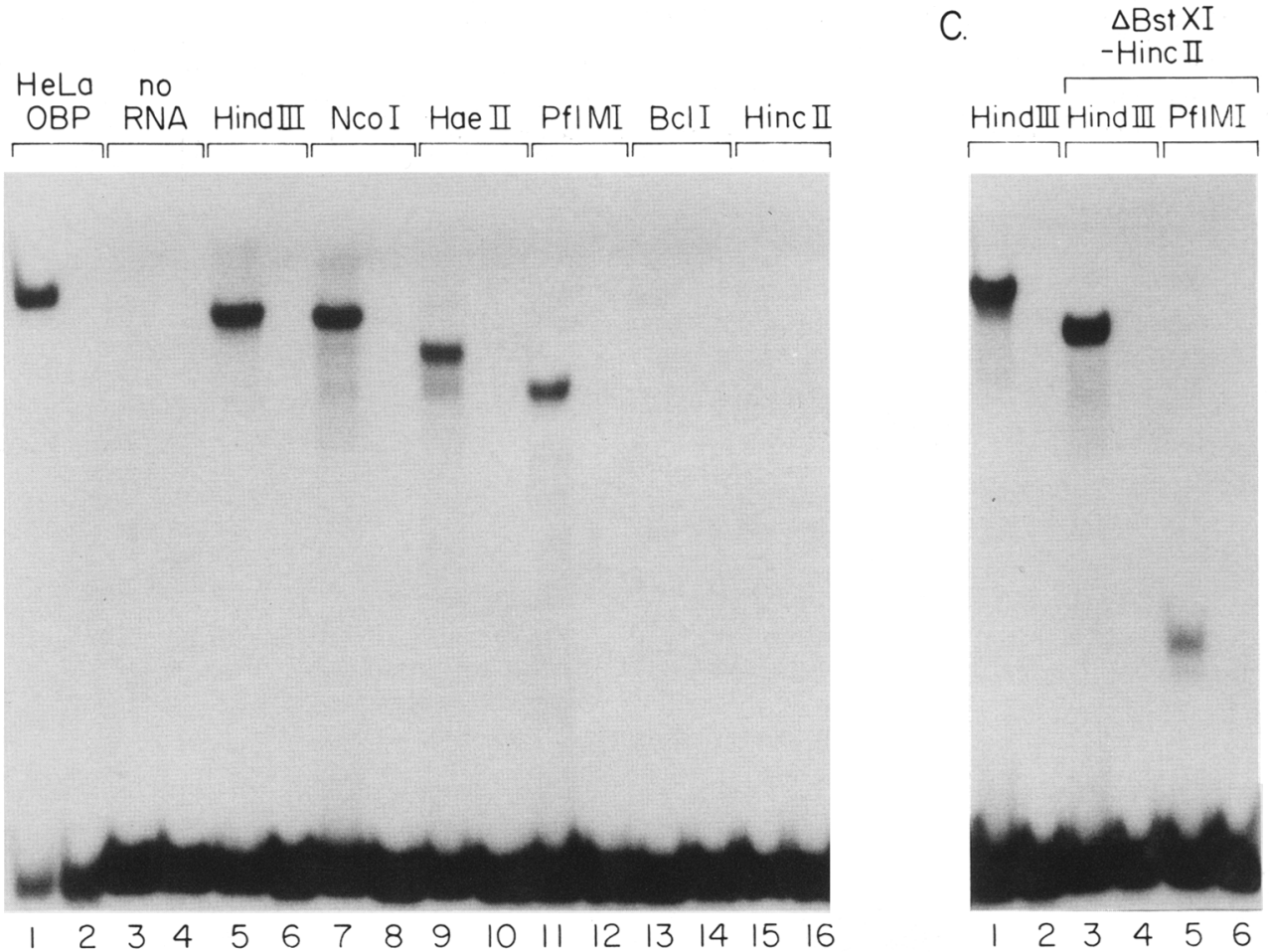

Figure 7. (See facing page for legend.) 
(Pruijn et al. 1986; O'Neill and Kelly 1988), and OBP100 (Sturm et al. 1987). The arguments in favor of this interpretation are severalfold. First, the cloned octamerbinding protein has the same flexible DNA-binding specificity as HeLa cell Oct-1 protein. Second, the oct-1 gene is expressed in all of the five human and two mouse cell lines we examined and is thus expressed ubiquitously. Third, polyclonal rabbit antiserum raised against the cloned $\lambda \mathrm{C} 5$ gene product shows an antigenic relationship between the ubiquitous octamer-binding protein and the ubiquitously expressed oct-1 gene. Fourth, the oct-1 in vitro translation product is nearly the same size as the authentic HeLa cell octamer-binding protein (see the similarly sized complexes formed in Fig. 7). Thus, oct-1 apparently encodes both a transcription factor (OTF-1) and an adenovirus replication factor (NFIII) (O'Neill et al. 1988), in a manner similar to CTF/ NFI (Santoro et al. 1988).

We do not know, however, whether the actual polypeptide encoded by the $\lambda \mathrm{C} 5$ clone can activate either transcription or replication, or both. Multiple Oct-1 species may exist that are of similar size but are generated by alternative splicing of the primary oct-1 transcript, and these may have different functions (e.g., activation of different promoters). Different CTF/NFI polypeptides encoded by alternatively spliced mRNAs have already been described, and these polypeptides have different transcription and replication activities (Santoro et al. 1988). In vivo expression studies of the Oct-1 protein from the cloned gene have been hampered by the ubiquitous endogenous expression of this protein. Nevertheless, if the Oct- 1 protein encoded by the $\lambda \mathrm{C} 5 \mathrm{cDNA}$ is coexpressed with a U2 snRNA promoter containing multimerized octamer motifs (see Tanaka et al. 1988), U2 transcription is weakly activated (M. Tanaka, N. Hernandez, and W. Herr, unpubl.). We are presently analyzing more oct-1 cDNA clones to determine whether the oct-1 transcript is alternatively spliced and to perform a functional analysis of the Oct-1 protein.

\section{Oct-1 and Oct-2 share highly related DNA-binding domains}

One of the major interests in determining the structure of the ubiquitous and lymphoid-specific octamerbinding proteins is to compare two proteins that bind to DNA with indistinguishable sequence specificity, but display different patterns of transcriptional activation. The amino acid sequence comparison shown in Figure $6 \mathrm{~A}$ and the mapping of the DNA-binding domain of these two proteins (Fig. 7; Clerc et al. 1988) show that the regions responsible for octamer-specific DNA binding are very closely related. We do not know which regions are responsible for the trans-activation activities of these two proteins, but the different activities of the octamer motif in cell-specific, compared with ubiquitously expressed, promoters suggest that the regions of nonsimilarity between Oct- 1 and Oct- 2 are responsible for trans-activation. For example, the highly acidic domain (EEPSDLEELE; residues 280-289 in Oct-1) shared between Oct-1 and Oct-2 is probably not sufficient for activation of mRNA promoters because the octamer motif does not activate such promoters in the presence of Oct-1 (e.g., HeLa cells). This acidic domain is also probably not directly involved in activation of snRNA promoters by Oct-1 because an acidic GAL4 transactivation domain does not activate a U2 snRNA promoter containing GAL4 DNA-binding sites (Tanaka et al. 1988). The region of highest divergence between Oct-1 and Oct- 2 is within the carboxy-terminal domain, in which the Oct-2 protein contains a leucine zipper motif (Landschulz et al. 1988a; Clerc et al. 1988). Perhaps this motif permits specific protein-protein interactions that confer activation of mRNA-encoding promoters.

The high degree of amino acid sequence similarity within the DNA-binding domains of Oct-1 and Oct-2 suggests that the oct-1 and oct-2 genes arose by duplication of a common ancestral gene. This high degree of amino acid sequence conservation appears to have been selected for strongly during evolution because comparison of the oct-1 and oct-2 (Clerc et al. 1988) nucleotide sequences encoding the 75-amino-acid-long region of highest identity (the POU-specific box) shows that $52 \%$ of the silent coding positions differ at the nucleotide level. This represents very little sequence conservation at these positions, strongly arguing that the similar amino acid sequences have been selected for at the level of the protein. What selective pressure may have maintained this remarkable degree of amino acid sequence conservation within the POU domain? Because these proteins bind indistinguishably to the same DNA sequences (Staudt et al. 1986), a clear possibility is that the entire region is conserved to maintain the same DNAbinding specificity. Pit-1 represents the other member of the POU family for which the DNA-binding site has been well characterized (Nelson et al. 1988). Curiously, this protein, in which the POU domain is less closely related to Oct- 1 and Oct- 2 than Oct-1 and Oct- 2 are to themselves (see Herr et al. 1988), binds to a different, yet related, sequence motif (ATGNATA $\mathrm{A} / \mathrm{T} / \mathrm{A} T$, compared with ATGCAAAT; Nelson et al. 1988). These comparisons suggest that the POU domain as a whole may bind to a similar class of DNA-binding sites and, conversely, that at least some of the differences between the Oct and Pit-1 POU domains are responsible for the differences in DNA sequence recognition.

One of the surprising results in the analysis of the Pit-1 (Nelson et al. 1988) and Oct-1 (OBP100; Baumruker et al. 1988) DNA-binding specificities is that the individual proteins can bind to very dissimilar DNA sequences. We have shown that Oct-1 protein can bind to sequences that are identical at only 4 out of 14 positions (AGTATGCAAAGCAT and GGCATCTCATTACC); nevertheless, simple point mutations within Oct-1 DNA-binding sites can abolish Oct-1 DNA binding. Therefore, Oct-1 exhibits a flexible, yet specific, pattern of DNA-binding site selection. This pattern of diverse sequence recognition is also exhibited by the Drosophila eve-encoded homeo box protein (Hoey and Levine 1988). In the case of eve, Hoey et al. (1988) have shown that the protein context of the homeo box is important in defining the relaxed binding specificity of the 
Eve protein. In our studies, we have shown that the Oct-1 homeo box domain is essential for DNA-binding activity (Fig. 7). By analogy to Eve, the POU-specific box that flanks the homeo box domain in Oct-1 may reflect a highly conserved protein context that allows a POU class of homeo box domains to bind to a specific yet degenerate set of DNA-binding sites. Alternatively, the POU domain may not be involved in DNA binding but, rather, may be responsible for interaction with other proteins involved in transcription. At present, we favor the involvement of the POU-specific box in DNA binding because of the correlation between the degree of similarity in DNA-binding specificity and the degree of similarity in POU domain sequence among the Oct-1, Oct-2, and Pit-1 proteins.

\section{The POU family of proteins represents a new class of homeo box proteins with ubiquitous and cell-specific members}

The majority of vertebrate homeo box genes have been cloned by cross-hybridization to either Drosophila or other vertebrate homeo box domains (for review, see Dressler and Gruss 1988), whereas the POU homeo box proteins were identified by either biochemical (Oct-1, Oct-2, and Pit-1) or genetic (unc-86) assays. Now that this new family of homeo box proteins has been identified, hybridization studies with sequences from the POU domain may uncover more members of this class of homeo box proteins. The identification of both cell-specific and ubiquitously expressed transcription factors, along with a $C$. elegans gene product involved in regulating cell fate, affords a new perspective on homeo box proteins and the POU domain. The presence of wellcharacterized transcription factors in this class shows that homeo box proteins can be positive activators of gene expression. The cell-specific members show that these trans-activators can determine cellular differentiation and cell lineage (Clerc et al. 1988; Finney et al. 1988; Ingraham et al. 1988). The Oct-1 protein is unique in that it is a transcription (and DNA replication) factor with a homeo box domain that is ubiquitously expressed in different cell types. This result suggests that the homeo box is one of several possible DNA-binding motifs (like zinc fingers) that is used by both general and cell-specific transcription factors to regulate gene expression by sequence-specific DNA binding.

\section{Materials and methods}

Isolation of $\lambda C 5$ from an NTera-2D1 $\lambda g t 11$ cDNA library

An amplified $\lambda$ gt 11 library made from cytoplasmic polyadenylated RNA of NTera-2Dl human teratocarcinoma cells, using oligo(dT) primer (SenGupta et al. 1986), was screened by the in situ filter detection method of Vinson et al. (1988). Recombinant phage at $4 \times 10^{5}$ were screened at a density of $2 \times 10^{4}$ per filter after lytic infection of $E$. coli strain Y1090 (Young and Davis 1983). The probe used in screening the filters was prepared by nick-translation (Maniatis et al. 1982) of purified $14 \times$ B17 HindIII - PstI restriction fragment (Ondek et al. 1987), which contains 14 reiterated copies of SV40 Octal motif (Sturm et al. 1987). One positive plaque, named $\lambda C 5$, bound the $14 \times \mathrm{B} 17$ probe in duplicate with high affinity and was subsequently purified by three rounds of plaque purification (Maniatis et al. 1982) using the same in situ binding procedure. Bacteriophage L20 encoding the DNA-binding domain of C/EBP linked to $\beta$-galactosidase (Landshulz et al. 1988b) was used as a negative control for nonspecific binding of the radiolabeled $14 \times \mathrm{B} 17$ probe to $\lambda \mathrm{gt} 11$ recombinant plaques, and a C/EBP. binding site probe (Vinson et al. 1988) was used to test the sequence-specificity of $\lambda$ C5 DNA binding.

\section{Production of $\beta$-galactosidase fusion protein, Southwestern blotting, and gel retardation analysis}

Phage stocks of $\lambda$ gt11, L20, and $\lambda$ C5 were prepared from plate lysates of Y1090 (Maniatis et al. 1982) and used to infect a culture of Y1089 (Young and Davis 1983) in log-phase growth. An overnight culture of Y1089 was diluted 1:50 in phage broth (L-broth, $10 \mathrm{~mm}$ Tris- $\mathrm{HCl}$ at $\mathrm{pH} 7.5,10 \mathrm{mM} \mathrm{MgSO}_{4}$ ) and grown for $1 \mathrm{hr}$; the cells were pelleted by centrifugation and resuspended in 0.2 volumes of fresh broth. Infections were done at an estimated moi of 5 for $10 \mathrm{~min}$ at room temperature, after which two volumes of phage broth prewarmed to $45^{\circ} \mathrm{C}$ was added and the culture grown for $10 \mathrm{~min}$ at $42^{\circ} \mathrm{C}$. Synthesis of the $\beta$-galactosidase fusion protein was induced subsequently by addition of IPTG to $10 \mathrm{mM}$ and incubation at $37^{\circ} \mathrm{C}$ for $1-2 \mathrm{hr}$ before the cells were collected by centrifugation.

When total protein synthesis was examined, the cells were resuspended in SDS-loading buffer and heated to $90^{\circ} \mathrm{C}$ for 10 min before sample loading onto SDS-polyacrylamide gels. For Southwestern blot analysis, the proteins resolved on SDS-polyacrylamide gels were transferred electrophoretically from the gel to nitrocellulose at $100 \mathrm{~mA}$ for $12 \mathrm{hr}$ in $25 \mathrm{~mm}$ Tris/190 mM glycine. The filters were then probed according to the protocol of Miskimins et al. (1985), using the same probe and buffer system used to screen the $\lambda$ gt 11 recombinant phage filters (see above; Vinson et al. 1988).

For gel retardation analysis, $\lambda C 5$-infected extract was prepared from the cell pellet by first resuspending and repelleting the cells in $1 \mathrm{ml}$ of ice-cold $50 \mathrm{mM}$ Tris- $\mathrm{HCl}(\mathrm{pH} \mathrm{7.4)}$, and $5 \mathrm{mM}$ EDTA, followed by resuspension in $1 \mathrm{ml}$ of $50 \mathrm{mM}$ Tris- $\mathrm{HCl}$ (pH 7.4), $200 \mathrm{~mm} \mathrm{NaCl}, 1 \mathrm{~mm}$ EDTA, $1 \mathrm{~mm}$ dithiothreitol (DTT), $0.1 \%$ NP-40, 10\% glycerol, $5 \mathrm{M}$ urea, and cell lysis by sonication. Insoluble material was removed by a 10-min Eppendorf centrifugation, and the supernatant was dialyzed against $50 \mathrm{~mm}$ Tris- $\mathrm{HCl}, 150 \mathrm{~mm} \mathrm{NaCl}, 1 \mathrm{~mm}$ EDTA, $1 \mathrm{~mm}$ DTT, $0.1 \%$ NP-40, and $10 \%$ glycerol to allow renaturation of DNA-binding activity. The HeLa cell heparin/agarose-fractionated extract was the same as that described previously (Sturm et al. 1987). A nuclear extract (Dignam et al. 1983) prepared from the BJAB lymphoma cell line was the source of NF-A2 gel shifting activity (Staudt et al. 1986). The H9 T-lymphoma cell heparinagarose fraction enriched for SRF was a gift from Dr. W. Ryan. Gel retardation analysis was performed as described previously (Sturm et al. 1987), with the modification of preincubating the extract with the binding mix for $10 \mathrm{~min}$ before addition of radiolabeled probe.

The probes for gel retardation were $3^{\prime}{ }^{32} \mathrm{P}$-end-labeled restriction fragments obtained from the following plasmids: pUC119CoreA/CoreA ${ }^{-}$(CoreA probe), pUC119B20wt ${ }^{+}$(SV40 site I Octal probe), and pUC119B20 dpm $8^{+}$(SV40 site I dpm 8 probe). These plasmids were constructed by ligation into the SmaI site of pUC119 end-filled 28-bp XhoI-digested monomer fragments isolated from the plasmids $\mathrm{p} \beta 6 \mathrm{xCoreA} /$ CoreA,

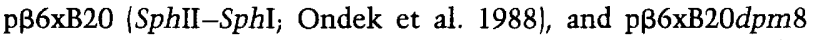
(Tanaka et al. 1988). These fragments were resected for end-la- 
beling as $E c o \mathrm{RI}-P s t \mathrm{I}$ fragments. The IgH enhancer probe was a HindIII-PstI fragment from $\mathrm{pBIgH}^{+}$(Sturm et al. 1987), the TAATGARAT probe was an EcoRI-PstI fragment from cloned synthetic oligomers in pUC119 (Baumruker et al. 1988), and the SRE probe was an EcoRI-HindIII fragment from pUC119 containing a synthetic SRE site cloned into the HincII site (Gilman 1988).

\section{Cell culture, RNA preparation, and RNase protection}

The NTera-2D1, WI-38, and BJAB cells were obtained from P. Andrews (Wistar Institute), E. Moran (Cold Spring Harbor Laboratoryl, and P. Sharp (MIT), respectively. NTera-2D1, WI-38, HeLa, 293, NS-1, and NIH/3T3 cells were grown in $10 \%$ fetal bovine serum in Dulbecco's modified Eagle's minimal medium with $100 \mathrm{U} / \mathrm{ml}$ penicillin and $100 \mu \mathrm{g} / \mathrm{ml}$ streptomycin. BJAB cells were grown in $10 \%$ fetal bovine serum in RPMI medium suplemented with $50 \mu \mathrm{M}$ mercaptoethanol. Spinner HeLa cells were grown to a density of $4 \times 10^{5}$ cells $/ \mathrm{ml}$ in $5 \%$ calf serum. Cytoplasmic RNAs were prepared by NP-40 lysis, as described previously (Shepard et al. 1988), except that the DNase I digestion step was not included. The T3 RNA polymerase antisense oct-1 probe was prepared from a HaelII-digested subclone of the $5^{\prime} 1.1-\mathrm{kb} \lambda \mathrm{C} 5$ EcoRI fragment into the EcoRI site of pBSM13+ (Stratagene) (called pBS $\lambda \mathrm{C} 51.1^{+}$), generating a probe that spanned from nucleotide 642 to 1109 in the oct-1 sequence shown in Figure 5A. The probe was labeled with $[\alpha-32 \mathrm{P}] \mathrm{CTP}$ at $400 \mathrm{Ci} / \mathrm{mmole}$ and purified by polyacrylamide gel electrophoresis. The probe was hybridized overnight to the different cytoplasmic RNAs treated with RNase $A$ and $T_{1}$, and fractionated on $6 \%$ denaturing polyacrylamide gels, as described previously (Zinn et al. 1983).

\section{Generation and use of rabbit anti-Oct-1 antisera}

$\lambda$ C5 fusion protein expressed in Y1089, as described above, was purified for use as antigen by preparative SDS-polyacrylamide gel electrophoresis of the total protein lysate on $4 \%$ polyacrylamide gels. The $190-\mathrm{kD} \beta$-galactosidase-octamer-binding fusion protein was visualized by briefly staining the gel with $0.05 \%$ Coomassie Brilliant Blue R-250 in water and then destaining with several changes of water. For the first injection of two New Zealand white rabbits, gel slices containing $\sim 50 \mu \mathrm{g}$ of fusion protein were macerated by passing through a syringe repeatedly and emulsified in Freund's complete adjuvant (Harlow and Lane 1988). For subsequent injections, the fusion protein was recovered from the gel slice by electroelution into $3 \mathrm{ml}$ of $0.2 \mathrm{~m}$ Tris-acetate (pH 7.4), $1 \%$ SDS, $100 \mathrm{~mm}$ DTT, and precipitation with five volumes of acetone before resuspension in water and emulsifying in Freund's incomplete adjuvant. Preimmune serum was obtained before the first injection, and the rabbits were boosted every 2 weeks with $50 \mu \mathrm{g}$ of fusion protein after the first immunization. Five-milliliter test bleeds were obtained before each boosting to test for antibody production. One rabbit exhibited an immune response after the third injection, as assayed by Western blotting of the fusion protein. This antiserum was subsequently used for the gel retardation assays. anti-Oct- 1 antisera was added to the binding reaction, together with the cell extract in the $10-\mathrm{min}$ preincubation step in the absence of probe.

\section{Sequencing of oct-1 cDNAs}

Due to the presence of an internal EcoRI site, the cDNA insert of $\lambda \mathrm{C} 5$ was excised as two EcoRI fragments and subcloned into the EcoRI site of pUC118. The nucleotide sequence of each fragment was determined by the shotgun method (Bankier and Barrell 1983). To prepare the random shotgun subclones, each
EcoRI insert was isolated preparatively on a polyacrylamide gel, self-ligated with T4 ligase, sonicated, end-repaired, and fragments size-selected $(\sim 400-1000 \mathrm{bp})$ on a polyacrylamide gel. After elution, the fragments were blunt-end ligated into SmaIdigested and phosphatased M13mp8 phage vector. M13 singlestranded DNA templates were sequenced using the dideoxy method (Sanger et al. 1977), and the data collected and compiled in the Intelligenetics GENED program. Both fragments were sequenced in entirety on both strands. The junction between the two EcoRI sites was ascertained by sequencing across the site in the pBSoct-1+ clone described below.

To isolate additional oct-1 cDNAs, a $\lambda$ gt10 library of cytoplasmic polyadenylated RNA from NTera-2D1 human teratocarcinoma cells (Skowronski et al. 1988) was screened for oct-1 cDNA clones by hybridization using standard methods (Maniatis et al. 1982). Both of the 1.1- and 1.3-kb EcoRI fragments from $\lambda C 5$ were nick-translated and used as probe. After three rounds of plaque purification, DNA was prepared from each clone (Manfioletti and Schneider 1988), and the size of the cDNA inserts was determined by EcoRI digestion. This procedure resulted in the isolation of 16 new oct-1 cDNA clones. The longest clone obtained, $\lambda \mathrm{C} 7$, was sequenced by the dideoxy method (Sanger et al. 1977), using forward and reverse $\lambda$ gt 10 primers flanking the EcoRI cloning site according to the manufacturer's specifications (New England Biolabs), and also with a 21-nucleotide-long oligonucleotide corresponding to 23892409 of the oct 1 cDNA sequence shown in Figure 5 and directed toward the poly $(A)$ sequence.

\section{In vitro transcription/translation of oct-1 $\mathrm{cDNA}$}

To synthesize protein for the mapping of the Oct-1 DNAbinding domain, an Aval-HpaII restriction fragment that spans the entire oct-1-coding sequence and includes $13 \mathrm{bp}$ of downstream $\lambda$ gt 11 sequences from $\lambda \mathrm{C} 5$ was cloned into the HincII site of $\mathrm{pBSMl}^{+}$(Stratagene) by blunt-end ligation after endfilling of the $5^{\prime}$ overhanging termini. The AvaI site was created by the ligation of the EcoRI linker to the $5^{\prime}$ end of the oct-1 sequences in $\lambda C 5$ (CC/CGAG) and in the pBS subclone lies adjacent to the pBS EcoRI site. This plasmid is called pBSoct$1^{+}$. A BstXI-HincII deletion, $\mathrm{pBSoct}-1 \Delta \mathrm{BH}$, from this clone was made by digestion of plasmid DNA with these enzymes, bluntending of the $3^{\prime}$ BstXI overhang with the large fragment of DNA polymerase I, and recircularization with DNA ligase. Generation of the correct junction sequence was ascertained by DNA sequencing. Plasmid DNA from these constructs was digested with restriction endonucleases and used as template for T7 RNA polymerase to transcribe uncapped RNA suitable for in vitro translation. The RNA templates (about $1 \mu \mathrm{g}$ ) were used as mRNA in a rabbit reticulocyte lysate (Promega; $50 \mu \mathrm{l}$ total volume) to translate $\left.{ }^{35} \mathrm{~S}\right]$ methionine-labeled protein, according to the manufacturer's specifications, and protein production confirmed by analysis of the reaction products on SDS-polyacrylamide gels. Gel retardation analysis with ${ }^{32} \mathrm{P}$-radiolabeled DNA fragments was performed directly using $1 \mu l$ of the translation mix as described previously (Sturm et al. 1987) with the preincubation step described above. The gels were acid-fixed, dried, and exposed to two sheets of X-ray film to shield the top sheet from ${ }^{35} \mathrm{~S}$ radiation but still allow the ${ }^{32}$-labeled DNA fragments to be detected.

\section{Acknowledgments}

We thank S. McKnight, C. Vinson, and K. La Marco for teaching the 'Rapid Cloning of Genes encoding Sequence-Specific DNA Binding Proteins' course at the Waksman Institute, April 
21-22, 1988. We are indebted to J. Skowronski for the gift of the NTera-2D1 $\lambda$ gt 11 and $\lambda$ gt 10 cDNA libraries and for advice. We thank J. Clarke and M. Cleary for excellent technical assistance; $M$. Goodwin and J. Liebowitz for help in preparation of the manuscript; J. Duffy, D. Greene, and M. Ockler for artwork and photography; G. Otto and T. Burglin for computer analyses; $M$. Iacovacci and M. Zoller for oligonucleotide synthesis; B. Knowles, P. Andrews, B. Moran, and P. Sharp for gifts of cell lines; W. Ryan for the gift of SRE probe and SRF-containing extract; and E. Harlow for advice on antibody production and help with immunoprecipitation. We thank R. Clerc, P. Sharp, H. Ingraham, M. Rosenfeld, M. Finney, and G. Ruvkun for exchanging unpublished sequences and helpful discussions, and N. Hernandez, B. Stillman, and M. Gilman for critical readings of the manuscript. Last, we thank J.D. Watson for encouraging us to initiate this project. R.A.S. is a recipient of a Cancer Research Institute Fellowship (New York); G.D. was supported by a Long Island Biological Association (LIBA) postdoctoral fellowship; W.H. is a Rita Allen Foundation Scholar. This work was supported by U.S. Public Health Services grant CA-13106 from the National Cancer Institute.

\section{Note}

Sequence data described in this paper have been submitted to the EMBL/GenBank Data Libraries under accession number $\mathrm{X} 13403$.

\section{References}

Ares, M. Jr., M. Mangin, and A.M. Weiner. 1985. Orientationdependent transcriptional activator upstream of a human U2 snRNA gene. Mol. Cell. Biol. 5: 1560-1570.

Ares, M. Jr., J.-S. Chung, L. Giglio, and A.M. Weiner. 1987. Distinct factors with Spl and NF-A specificities bind to adjacent functional elements of the human U2 snRNA gene enhancer. Genes Dev. 1: 808-817.

Bankier, A.T. and B.G. Barrell. 1983. Shotgun DNA sequencing. In Techniques in the life sciences B5, Elsevier, Ireland.

Baumruker, T., R. Sturm, and W. Herr. 1988. OBP100 binds remarkably degenerate octamer motifs through specific interactions with flanking sequences. Genes Dev. 2:. 1400-1413.

Brent, R. and M. Ptashne. 1985. A eucaryotic transcriptional activator bearing the DNA specificity of a procaryotic repressor. Cell 43: 729-736.

Carbon, P., S. Murgo, J.-P. Ebel, A. Krol, G. Tebb, and I.W. Mattaj. 1987. A common octamer motif binding protein is involved in the transcription of U6 snRNA by RNA polymerase III and U2 snRNA by RNA polymerase II. Cell 51: $71-79$.

Clerc, R.G., L.M. Corcoran, J.H. LeBowitz, D. Baltimore, and P.A. Sharp. 1988. The B-cell specific Oct-2 protein contains POU-box and homeo-box-type domains. Genes Dev. 2: $1570-1581$.

Davidson, I., C. Fromental, P. Augereau, A. Wildeman, M. Zenke, and P. Chambon. 1986. Cell-type specific protein binding to the enhancer of simian virus 40 in nuclear extracts. Nature 323: 544-548.

Desplan, C., J. Theis, and P.H. O'Farrell. 1985. The Drosophila developmental gene, engrailed, encodes a sequence-specific DNA binding activity. Nature 318:630-635.

Dignam, J.D., R.M. Lebovitz, and R.G. Roeder. 1983. Accurate transcription initiation by RNA polymerase II in a soluble extract from isolated mammalian nuclei. Nucleic Acids Res. 11: $1475-1489$.

Dressler, G.R. and P. Gruss. 1988. Do multigene families regulate vertebrate development? Trends Genet. 4: 214-219.
Falkner, F.G. and H.G. Zachau. 1984. Correct transcription of an immunoglobulin $\kappa$ gene requires an upstream fragment containing conserved sequence elements. Nature 310: 71 74.

Finney, M., G. Ruvkun, and H.R. Horvitz. 1988. The C. elegans cell lineage and differentiation gene unc-86 encodes a protein containing a homeo domain and extended sequence similarity to mammalian transcription factors. Cell lin press).

Fletcher, C., N. Heintz, and R.G. Roeder. 1987. Purification and characterization of OTF-1, a transcription factor regulating cell cycle expression of a human histone $\mathrm{H} 2 \mathrm{~b}$ gene. Cell 51: 773-781.

Frederiksen, S., P. Hellung-Larsen, and E. Gram Jensen. 1978. The differential inhibitory effect of $\alpha$-amanitin on the synthesis of low molecular weight RNA components in BHK cells. FEBS Lett. 87: 227-231.

Gerster, T., P. Matthias, M. Thali, J. Jiricny, and W. Schaffner. 1987. Cell type-specificity elements of the immunoglobulin heavy chain gene enhancer. $E M B O$ I. 6: 1323-1330.

Gilman, M.Z. 1988. The c-fos serum response element responds to protein kinase C-dependent and -independent signals but not to cyclic AMP. Genes Dev. 2: 394-402.

Gram Jensen, E., P. Hellung-Larsen, and S. Frederiksen. 1979. Synthesis of low molecular weight RNA components A, C, and $D$ by polymerase II in $\alpha$-amanitin resistant hamster cells. Nucleic Acids Res. 6: 321-330.

Hanke, J.H., N.F. Landolfi, P.W. Tucker, and J.D. Capra. 1988. Identification of murine nuclear proteins that bind to the conserved octamer sequence of the immunoglobulin promoter region. Proc. Nat1. Acad. Sci. 85: 3560-3564.

Harlow, E. and D. Lane. 1988. Antibodies: A laboratory manual. Cold Spring Harbor Laboratory, Cold Spring Harbor, New York.

Herr, W., R.A. Sturm, R.G. Clerc, L.M. Corcoran, D. Baltimore, P.A. Sharp, H.A. Ingraham, M.G. Rosenfeld, M. Finney, G. Ruvkun, and H.R. Horvitz. 1988. The POU domain: A large conserved region in the mammalian pit-1, oct-1, oct-2, and Caenorhabditis elegans unc-86 gene products. Genes Dev. 2: 0000-0000.

Hoey, T. and M. Levine. 1988. Divergent homeo box proteins recognize similar DNA sequences in Drosophila. Nature 332: $858-861$.

Hoey, T., R. Warrior, J. Manak, and M. Levine. 1988. The DNA binding activities of the Drosophila melanogaster evenskipped protein are mediated by its homeo domain and influenced by protein context. Mol. Cell. Biol. 8: 4598-4607.

Hope, I.A. and K. Struhl. 1985. GCN4 protein, synthesized in vitro, binds his 3 regulatory sequences: Implications for general control of amino acid biosynthetic genes in yeast. Cell 43: $177-188$.

Ingraham, H.A., R. Chen, H.J. Mangalam, H.P. Elsholtz, S.E. Flynn, C.R. Lin, D.M. Simmons, L.W. Swanson, and M.G. Rosenfeld. 1988. A tissue specific transcription factor containing a homeo domain specifies a pituitary phenotype. Cell 55: 519-529.

Kadonaga, J.T., K.R. Carner, F.R. Masiarz, and R. Tjian. 1987. Isolation of cDNA encoding transcription factor $\mathrm{Spl}$ and functional analysis of the DNA binding domain. Cell 51: $1079-1090$.

Kakidani, H. and M. Ptashne. 1988. GAL4 activates gene expression in mammalian cells. Cell 52: 161-167.

Kozak, M. 1984. Compilation and analysis of sequences upstream from the translational start site in eukaryotic mRNAs. Nucleic Acids Res. 12: 857-872.

Kuenzel, E.A., J.A. Mulligan, J. Sommercorn, and E.G. Krebs. 
1987. Substrate specificity determinants for casein kinase II as deduced from studies with synthetic peptides. I. Biol. Chem. 262: 9136-9140.

LaBella, F., H.L. Sive, R.G. Roeder, and N. Heintz. 1988. Cellcycle regulation of a human histone $\mathrm{H} 2 \mathrm{~b}$ gene is mediated by the $\mathrm{H} 2 \mathrm{~b}$ subtype-specific consensus element. Genes Dev. 2: $32-39$.

Landolfi, N.F., J.D. Capra, and P.W. Tucker. 1986. Interaction of cell-type-specific nuclear proteins with immunoglobulin $\mathrm{V}_{\mathbf{H}}$ promoter region sequences. Nature 323: 548-551.

Landschulz, W.H., P.F. Johnson, and S.L. McKnight. 1988a. The leucine zipper: A hypothetical structure common to a new class of DNA binding proteins. Science 240: 1759-1764.

Landschulz, W.H., P.F. Johnson, E.Y. Adashi, B.J. Graves, and S.L. McKnight. 1988b. Isolation of a recombinant copy of the gene encoding C/EBP. Genes Dev. 2: 786-800.

Lenardo, M., J.W. Pierce, and D. Baltimore. 1987. Proteinbinding sites in Ig gene enhancers determine transcriptional activity and inducibility. Science 236: $1573-1577$.

Macdonald, P.M., P. Ingham, and G. Struhl. 1986. Isolation, structure, and expression of even-skipped: A second pairrule gene of Drosophila containing a homeo box. Cell 47: $721-734$.

Manfioletti, G. and C. Schneider. 1988. A new and fast method for preparing high quality lambda DNA suitable for sequencing. Nucleic Acids Res. 16: 2873-2884.

Mangin, M., M. Ares, Jr., and A.M. Weiner. 1986. Human U2 small nuclear RNA genes contain an upstream enhancer. EMBO I. 5: 987-995.

Maniatis, T., E.F. Fritsch, and J. Sambrook. 1982. Molecular cloning: A laboratory manual. Cold Spring Harbor Laboratory, Cold Spring Harbor, New York.

Mason, J.O., G.T. Williams, and M.S. Neuberger. 1985. Transcription cell type specificity is conferred by an immunoglobulin $\mathrm{V}_{\mathrm{H}}$ gene promoter that includes a functional consensus sequence. Cell 41: 479-487.

Mattaj, I.W., S. Lienhard, J. Jiricny, and E.M. De Robertis. 1985. An enhancer-like sequence within the Xenopus U2 gene promoter facilitates the formation of stable transcription complexes. Nature 316: 163-167.

McGinnis, W., M.S. Levine, E. Hafen, A. Kuroiwa, and W.J. Gehring. 1984. A conserved DNA sequence in homoeotic genes of the Drosophila Antennapedia and bithorax complexes. Nature 308: 428-433.

Miskimins, W.K., M.P. Roberts, A. McClelland, and F.H. Ruddle. 1985. Use of a protein-blotting procedure and a specific DNA probe to identify nuclear proteins that recognize the promoter region of the transferrin receptor gene. Proc. Natl. Acad. Sci. 82: 6741-6744.

Nelson, C., V.R. Albert, H.P. Elsholtz, L.I.-W. Lu, and M.G. Rosenfeld. 1988. Activation of cell-specific expression of rat growth hormone and prolactin genes by a common transcription factor. Science 239: 1400-1405.

Ondek, B., L. Gloss, and W. Herr. 1988. The SV40 enhancer contains two distinct levels of organization. Nature 333: $40-45$.

Ondek, B., A. Shepard, and W. Herr. 1987. Discrete elements within the SV40 enhancer region display different cell specific enhancer activities. EMBO J. 6: 1017-1025.

O'Neill, E.A. and T.J. Kelly. 1988. Purification and characterization of nuclear factor III (origin recognition protein C) a sequence-specific DNA binding protein required for efficient initiation of adenovirus DNA replication. I. Biol. Chem. 263: 931-937.

O'Neill, E.A., C. Fletcher, C.R. Burrow, N. Heintz, R.G. Roeder, and T.J. Kelly. 1988. Transcription factor OTF-1 is function- ally identical to the DNA replication factor NFIII. Science 241: 1210-1213.

Pabo, C.O. and R.T. Sauer. 1984. Protein-DNA recognition. Annu. Rev. Biochem. 53: 293-321.

Parslow, T.G., D.L. Blair, W.J. Murphy, and D.K. Granner. 1984. Structure of the $5^{\prime}$ ends of immunoglobulin genes: A novel conserved sequence. Proc. Natl. Acad. Sci. 81: 2650-2654.

Poole, S.J., L.M. Kauvar, B. Drees, and T. Kornberg. 1985. The engrailed locus of Drosophila: Structural analysis of an embryonic transcript. Cell 40: 37-43.

Pruijn, G.J.M., W. van Driel, and P.C. van der Vliet. 1986. Nuclear factor III, a novel sequence-specific DNA-binding protein from HeLa cells stimulating adenovirus DNA replication. Nature 322: 656-659.

Ptashne, M. 1988. How eucaryotic transcriptional activators work. Nature 363: 683-689.

Rosales, R., M. Vigneron, M. Macchi, I. Davidson, J.H. Xiao, and P. Chambon. 1987. In vitro binding of cell-specific and ubiquitous nuclear proteins to the octamer motif of the SV40 enhancer and related motifs present in other promoters and enhancers. EMBO J. 6: 3015-3025.

Rosenfeld, P.J., E.A. O'Neill, R.J. Wides, and T.J. Kelly. 1987. Sequence-specific interactions between cellular DNAbinding proteins and the adenovirus origin of DNA replication. Mol. Cell. Biol. 7: 875-886.

Sanger, F., S. Nicklen, and A.R. Coulson. 1977. DNA sequencing with chain-terminating inhibitors. Proc. Natl. Acad. Sci. 74: 5463-5467.

Santoro, C., N. Mermod, P.C. Andrews, and R. Tjian. 1988. A family of human CCAAT-box-binding proteins active in transcription and DNA replication: Cloning and expression of multiple cDNAs. Nature 334: 218-224.

Scheidereit, C., A. Heguy, and R.G. Roeder. 1987. Identification and purification of a human lymphoid-specific octamer binding protein (OTF-2) that activates transcription of an immunoglobulin promoter in vitro. Cell 51: 783-793.

Schneuwly, S., A. Kuroiwa, P. Baumgartner, and W.J. Gehring. 1986. Structural organization and sequence of the homeotic gene Antennapedia of Drosophila melanogaster. EMBO J. 5: $733-739$.

Scott, M.P. and A.J. Weiner. 1984. Structural relationships among genes that control development: sequence homology between the Antennapedia, Ultrabithorax, and fushi tarazu loci of Drosophila. Proc. Natl. Acad. Sci. 81: 4115-4119.

Scott, M.P., J.W. Tamkun, and G.W. Hartzell. 1989. The structure and function of the homeo domain. BBA Rev. Cancer (in press).

SenGupta, D.N., B.Z. Zmudzka, P. Kumar, F. Cobianchi, J. Skowronski, and S.H. Wilson. 1986. Sequence of human DNA polymerase $\beta \mathrm{mRNA}$ obtained through cDNA cloning. Biochem. Biophys. Res. Commun. 136: 341-347.

Shepard, A., J. Clarke, and W. Herr. 1988. Simian virus 40 revertant enhancers exhibit restricted host ranges for enhancer function. I. Virol. 62: 3364-3370.

Singh, H., R. Sen, D. Baltimore, and P.A. Sharp. 1986. A nuclear factor that binds to a conserved sequence motif in transcriptional control elements of immunoglobulin genes. Nature 319: $154-158$.

Singh, H., J.H. LeBowitz, A.S. Baldwin, Jr., and P.A. Sharp. 1988. Molecular cloning of an enhancer binding protein: Isolation by screening of an expression library with a recognition site DNA. Cell 52: 415-423.

Skowronski, J., T.G. Fanning, and M.F. Singer. 1988. Unitlength line-1 transcripts in human teratocarcinoma cells. Mol. Cell. Biol. 8: 1385-1397.

Staudt, L.M., R.G. Clerc, H. Singh, J.H. Lebowitz, P.A. Sharp, 
and D. Baltimore. 1988. Cloning of a lymphoid-specific cDNA encoding a protein binding the regulatory octamer DNA motif. Science 241: 577-580.

Staudt, L.M., H. Singh, R. Sen, T. Wirth, P.A. Sharp, and D. Baltimore. 1986. A lymphoid-specific protein binding to the octamer motif of immunoglobulin genes. Nature 323: 640643.

Sturm, R.A., S. Dalton, and J.R.E. Wells. 1988. Conservation of histone $\mathrm{H} 2 \mathrm{~A} / \mathrm{H} 2 \mathrm{~B}$ intergene regions: a role for the $\mathrm{H} 2 \mathrm{~B}$ specific element in divergent transcription. Nucleic Acids Res. 16: $8571-8586$.

Sturm, R., T. Baumruker, B.R. Franza, Jr., and W. Herr. 1987. A $100-\mathrm{kD}$ HeLa cell octamer binding protein (OBP100) interacts differently with two separate octamer-related sequences within the SV40 enhancer. Genes Dev. 1: 11471160.

Tanaka, M., U. Grossniklaus, W. Herr, and N. Hernandez. 1988. Activation of the U2 snRNA promoter by the octamer motif defines a new class of RNA polymerase II enhancer elements. Genes Dev. 2: (in press).

Vinson, C.R., K.L. LaMarco, P.F. Johnson, W.H. Landschulz, and S.L. McKnight. 1988. In situ detection of sequence-specific DNA binding activity specified by a recombinant bacteriophage. Genes Dev. 2: 801-806.

Webster, N., J.R. Jin, S. Green, M. Hollis, and P. Chambon. 1988. The yeast $\mathrm{UAS}_{\mathrm{G}}$ is a transcriptional enhancer in human HeLa cells in the presence of the GAL4 trans-activator. Cell 52: 169-178.

Westin, G. and W. Schaffner. 1988. Heavy metal ions in transcription factors from HeLa cells: Spl, but not octamer transcription factor requires zinc for DNA binding and for activator function. Nucleic Acids Res. 16: 5771-5781.

Winter, E., F. Yamamoto, C. Almoguera, and M. Perucho. 1985. A method to detect and characterize point mutations in transcribed genes: Amplification and overexpression of the mutant c-Ki-ras allele in human tumor cells. Proc. Natl. Acad. Sci. 82: 7575-7579.

Wirth, T., L. Staudt, and D. Baltimore. 1987. An octamer oligonucleotide upstream of a TATA motif is sufficient for lymphoid-specific promoter activity. Nature 329: 174-178.

Young, R.A. and R.W. Davis. 1983. Yeast RNA polymerase II genes: Isolation with antibody probes. Science 222: 778782.

Zinn, K., D. DiMaio, and T. Maniatis. 1983. Identification of two distinct regulatory regions adjacent to the human $\beta$-interferon gene. Cell 34: 865-879. 


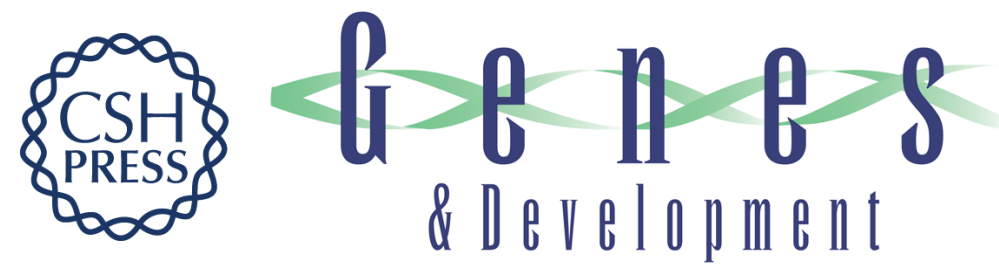

\section{The ubiquitous octamer-binding protein Oct-1 contains a POU domain with a homeo box subdomain.}

R A Sturm, G Das and W Herr

Genes Dev. 1988, 2:

Access the most recent version at doi:10.1101/gad.2.12a.1582

References This article cites 71 articles, 27 of which can be accessed free at:

http://genesdev.cshlp.org/content/2/12a/1582.full.html\#ref-list-1

License

Email Alerting

Service

Receive free email alerts when new articles cite this article - sign up in the box at the top right corner of the article or click here.

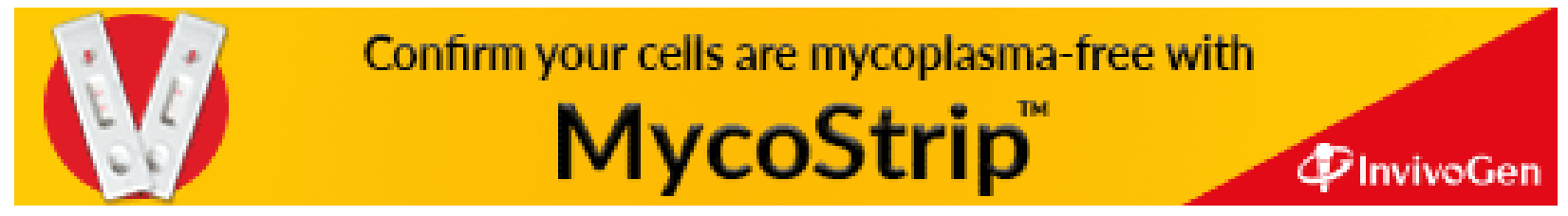

